\title{
A review on the syntheses of Dronabinol and Epidiolex as classical cannabinoids with various biological activities including those against SARS-COV2
}

\author{
Neda Tadayon ${ }^{1} \cdot$ Ali Ramazani $i^{1,2,3,4}$ (D)
}

Received: 21 July 2020 / Accepted: 1 February 2021 / Published online: 26 February 2021

(C) Iranian Chemical Society 2021

\begin{abstract}
The very important psychoactive phytocannabinoid from Cannabis $\Delta^{9}$ tetrahydrocannabinol ( $\Delta^{9}$-THC) and its non-psychotropic member is cannabidiol (CBD). These compounds have a variety of pharmacological activities. THC has been approved for the treatment of nausea caused by chemotherapy, multiple sclerosis and chronic and neuropathic pain and research is underway to use it to treat stimulation of dementia, anorexia nervous and Tourette's syndrome. CBD has therapeutic benefits in Epilepsy, neuroprotective, cancer, inflammatory and anxiety. Recognizing candidate drugs efficiently in the new SARS-CoV2 disease 2019 (Covid-19) is crucial. Cannabidiol and $\Delta^{9}$-tetrahydrocannabinol have immunomodulatory and anti-inflammatory effects. They can reduce the uncontrolled cytokine production of acute lung injury. Although THD and CBD can be extracted from natural sources due to the disadvantages of this method such as difficulty in purification, cultivation, etc. It has been proven that chemical-synthesis methods of these two compounds can solve these problems. This review briefly summarizes the chemical-synthetic strategies of Dronabinol and Epidiolex from THC and CBD.
\end{abstract}

\section{Graphic abstract}

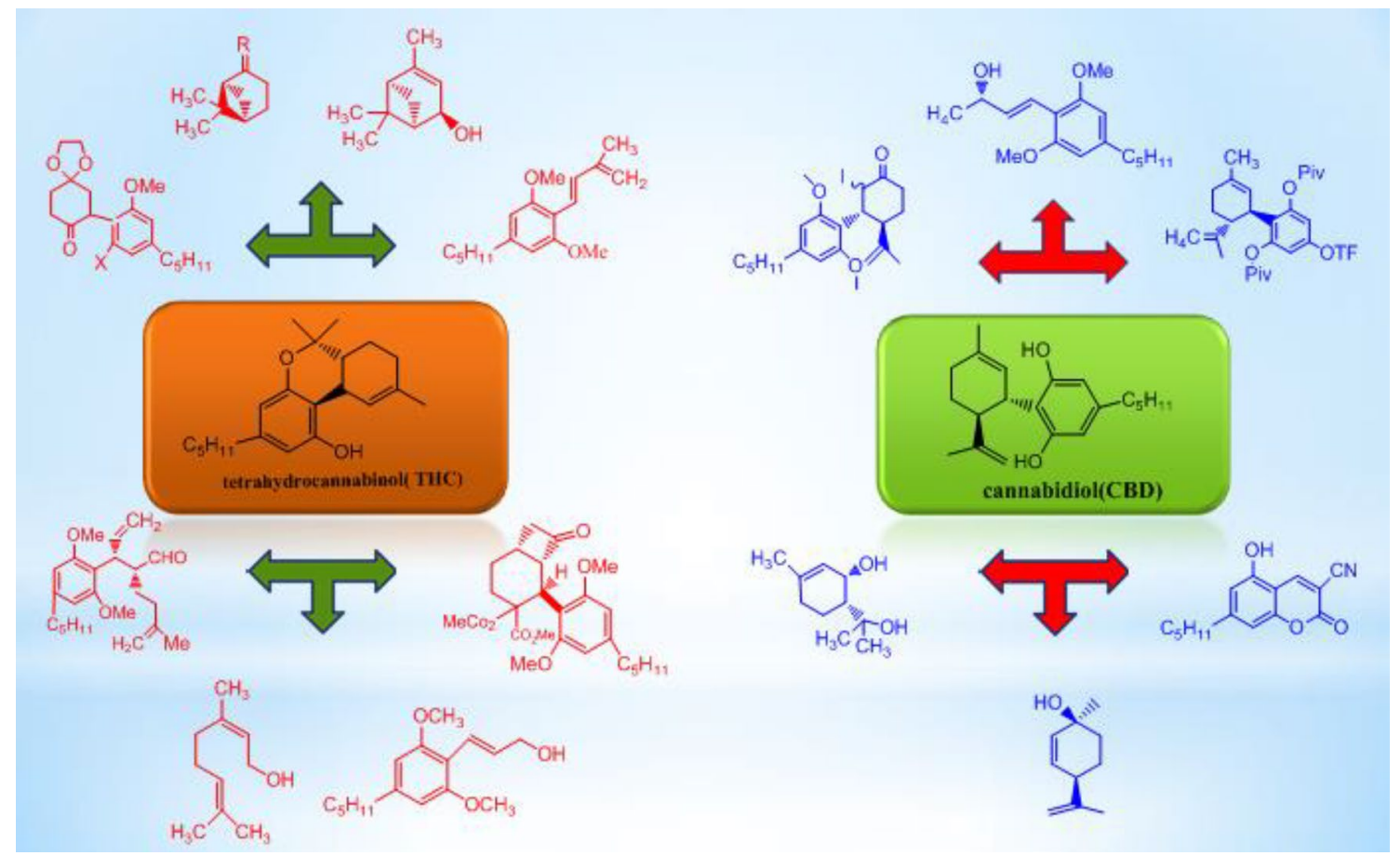

Extended author information available on the last page of the article 
Keywords Phytocannabinoid $\cdot \Delta^{9}$-Tetrahydrocannabinol $\cdot$ Cannabidiol $\cdot$ SARS-CoV2 $\cdot$ Covid-19 $\cdot$ Dronabinol $\cdot$ Epidiolex

\section{Introduction}

Cannabinoids are chemicals found by the purification and isolation in Cannabis Sativa [1]. More than 200 phytocannabinoids were identified including $\Delta^{9}$-tetrahydrocannabinol $\left(\Delta^{9}\right.$-THC, 1), cannabinol $(\mathrm{CBN})$, cannabidiolic acid (CBDA), cannabichromene (CBC), cannabidiol (CBD; 2) (Fig. 1), etc. [2-4]. $\Delta^{9}$-THC is the major psychoactive compound of cannabis that it's known in 1964 by Mechoulam and Gaoni [5, 6]. Cannabidiol was isolated by Adam et al. in 1940 and its structure was determined in 1963 by Mechoulam and Shvo; then the total configuration was determined as CBD in 1967 by Mechoulam and Gaoni [7-9]. CBD is a non-psychoactive phytocannabinoid [10]. Cannabinoids have pharmaceutical uses on two receptors called Cannabinoid receptor type 1 and type 2 (CB1\&CB2) [11-18]. The two receptors are widely found in the central nervous system and periphery [19]. CBD has little interest in these receptors; however, they can act as antagonists of the two receptors [20,21]. THC is a phytocannabinoid with psychoactive effects. In 2004, the use of a Cannabis sativa L. (Marijuana) extract was confirmed as a safe and effective treatment for HIV/AIDS, arising from anorexia and chemotherapy, from nausea and vomiting, multiple sclerosis through the United States Food and Drug Administration (USFDA) [22, 23]. The active ingredient of this approval medicine, Dronabinol (trade names Marinol and Syndros) is a purified Cannabisderived (-)- $\Delta^{9}$-trans-tetrahydrocannabinol $[24,25]$.

Dronabinol demonstrates very few psychoactive effects [26]. Accordingly, the World Health Organization (WHO) advised the THC for medical uses and low abuse potential in 2003 [27]. CBD is another cannabis extract that has nonpsychoactive effects. In 2018, the application of (-)-transcannabidiol was approved by the US Food and Drug Administration (USFDA) (brand name Epidiolex) for the treatment of patients with epileptic seizures related to Lennox-Gastaut syndrome and Dravet syndrome [28-31]. It also has shown a potential therapeutic advantage in autism, inflammation, cancer, and neurodegenerative diseases [32-41]. The appearance of SARS coronavirus 2 (SARS-CoV-2) at the end of 2019 in China has resulted in a large spread of the highly contagious and epidemic Covid-19 pandemic $[42,43]$. Infection is adjusted with numerous cytokines which act to proceed with inflammatory responses [44]. In several cases of viral infections a storm of cytokines and chemokines happens through infection [45]. Recent studies have demonstrated a series of anti-inflammatory, antioxidant and antiapoptotic properties of cannabinoids such as $\Delta^{9}$-tetrahydrocannabinol and cannabidiol in sepsis [46-53]. The connection between the cannabinoid system and sepsis can be explained via its effects on inflammation, on the immune system and on the redox activity (Fig. 2) [54]. By acting on special receptors, CBD/THC causes the repression of cytokine manufacturing, also to a reduction in redox mechanisms [55-60].

Phytocannabinoids have been obtained by extracting and purifying from the cannabis plant but their physical, chemical and structural similarities have become problematic [61]. Therefore, due to practical problems in purification and consistent quality control, the chemical synthesis route has better advantages. Considering the last two drugs made from cannabinoids and the chemical synthesis benefits of these compounds, in this review, we try to collect some of the recent publications about the chemical-synthesis strategies of cannabidiol and $\Delta^{9}$-tetrahydrocannabinol.

\section{Synthesis of $\Delta^{9}$-tetrahydrocannabinol ( $\Delta^{9}$-THC)}

Many synthetic pathways have been reported for the synthesis of $\Delta^{9}$-tetrahydrocannabinol. In 1967 , the primary synthetic route of $\Delta^{9}$-THC had published by Mechoulam et al. [62, 63]. In this method, they provided olivetylverbenyl by Friedel-Crafts alkylation in the presence of olivetol with (-)-cis/trans-verbenol in $p$-TSA or boron trifluoride. Olivetylverbenyl in the presence of boron trifluoride gave (-)- $\Delta^{8}$-THC up to $35 \%$ yield. Then, (-)- $\Delta^{8}$-THC was converted to (-)- $\Delta^{9}$-THC in $55 \%$ yield, by chlorination and elimination (Fig. 3).
Fig. 1 Structure of $\Delta^{9}$-THC (1) and cannabidiol (CBD, 2)

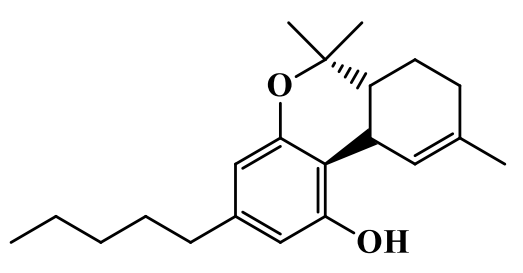

Tetrahydrocannabinol( THC),1

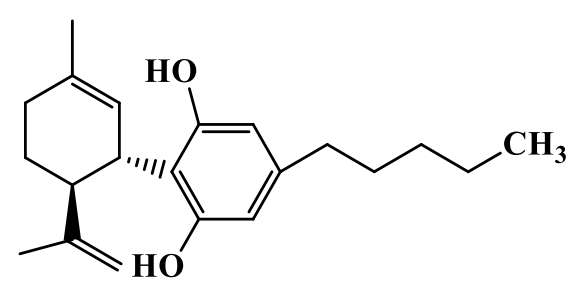

Cannabidiol(CBD), 2 


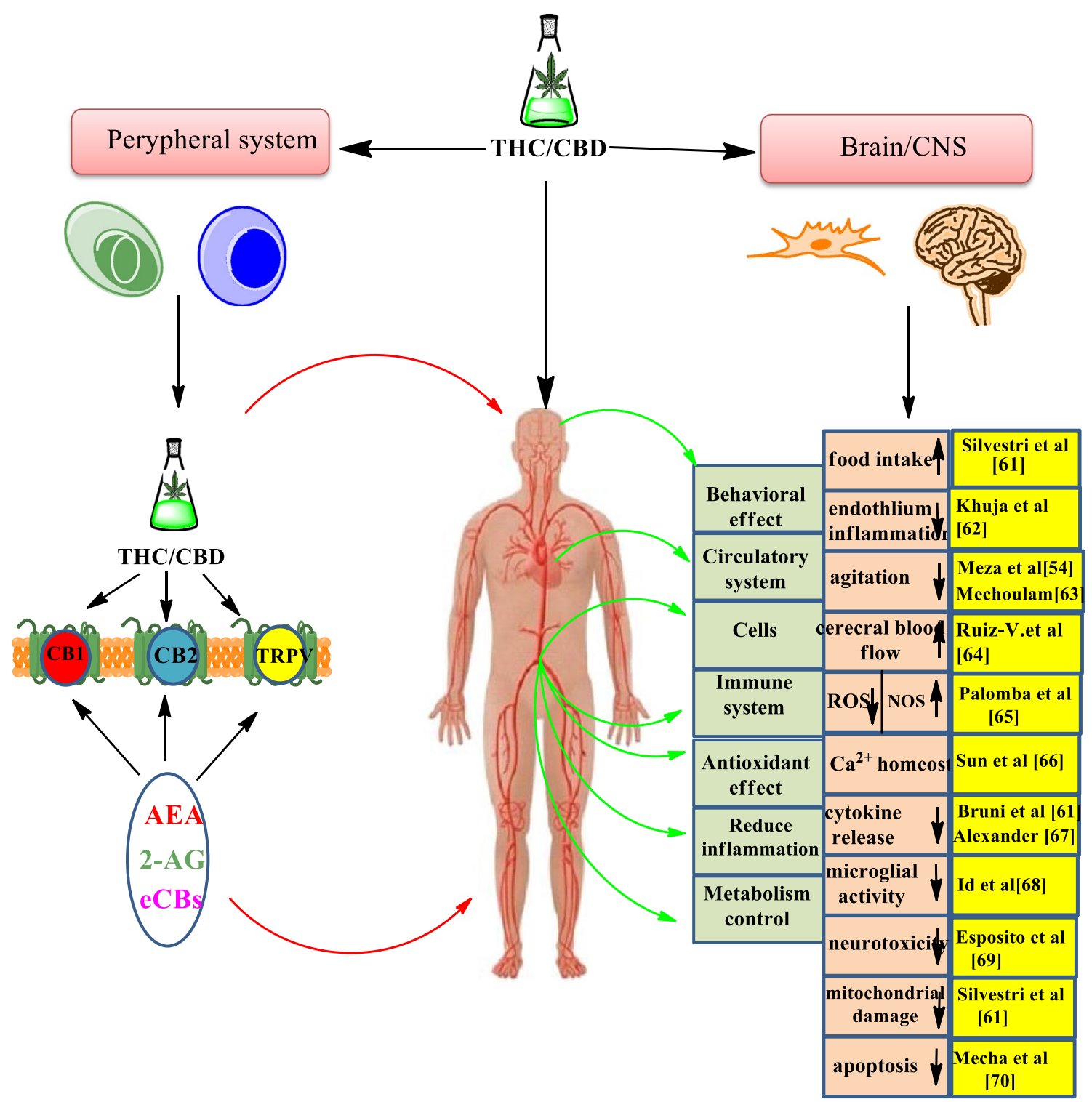

Fig. 2 Concepts of the endocannabinoid system in sepsis. TRPV: transient receptor potential vanilloid type 1; AEA: anandamide; 2-AG: 2-arachidonoylglycerol; eCBs: endogenous cannabinoids; ROS : reactive oxygen species; NOS: NO synthase protein

Fig. 3 Reagents: $\mathrm{B} \mathrm{BF}_{3} \cdot \mathrm{Et}_{2} \mathrm{O}$, $\mathrm{CH}_{2} \mathrm{Cl}_{2}$, rt; b $\rho$-TSA; c

$\mathrm{BF}_{3} \cdot \mathrm{Et}_{2} \mathrm{O}, \mathrm{CH}_{2} \mathrm{Cl}_{2}$, rt and $\mathbf{d} 1$. $\mathrm{HCl}, \mathrm{ZnCl}_{2}$, toluene. 2. $\mathrm{NaH}$, THF, reflux

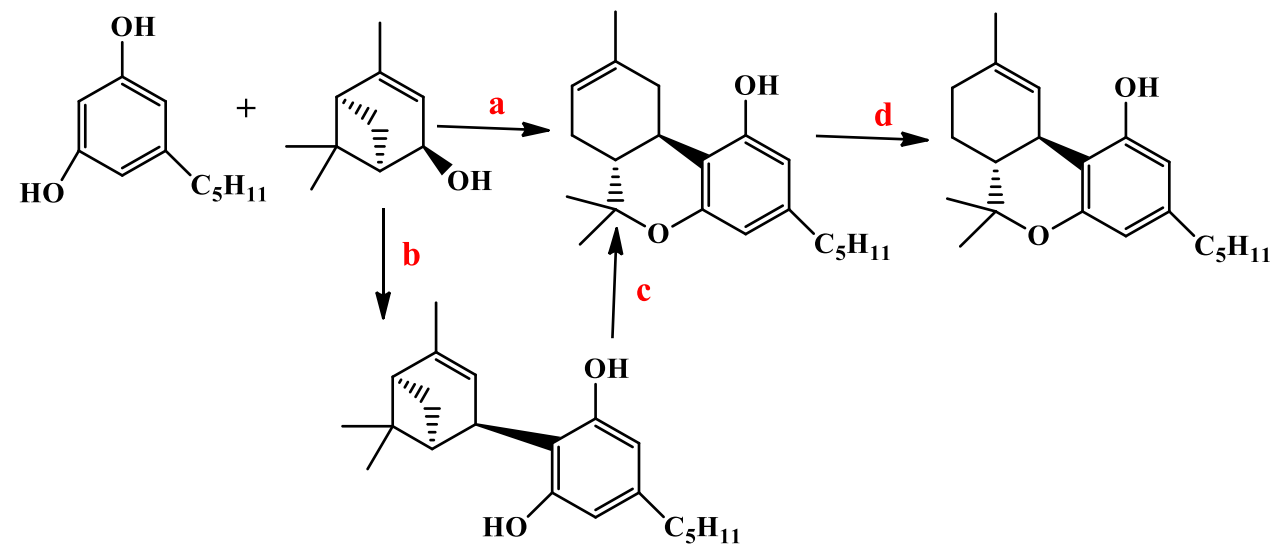


Razdan et al. reported the direct synthesis of $\Delta^{9}$-THC [64]. They used $p$-mentha-2, 8-dien-1-ol in the presence of olivetol, Lewis acid catalyst and $\mathrm{MgSO}_{4}$. Razdan's approach provided (-)-trans- $\Delta^{9}-\mathrm{THC}$ in $31 \%$ yield. This method is still used in the generation of (-)-trans- $\Delta^{9}$-THC because it is done in one step (Fig. 4).

Evans et al. reported the first asymmetric synthesis of $\Delta^{9}$ THC [65]. They used the Diels-Alder reaction of acryloyl oxazolidinone (diene) and l-acetoxy-3-methyl butadiene in the presence of the cationic bis(oxazoline) $\mathrm{Cu}$ (II) catalyst and was obtained acetylated cycloadduct. This cycloadduct with LiOBn and the addition of methylmagnesium bromide produced $p$-menth-1-ene-3,8-diol. The diol in the presence of olivetol and $p$-TSA afforded (+)-trans- $\Delta^{9}$-THC in $57 \%$ yield (Fig. 5).

Kobayashi et al. have reported a method for synthesis of $\Delta^{9}$-THC inclusive the three steps: (1) iodination of the 1-cyclohex-2-enone, (2) Boron trifluoride diethyl etherateassisted 1,4-addition of $\mathrm{Ar}_{2} \mathrm{Cu}(\mathrm{CN}) \mathrm{Li}_{2}$, (3) magnesium enolates were produced by $\alpha$-iodo aryl cyclohexanone with ethylmagnesium bromide [66]. This synthetic procedure used $\beta$-pinene and ozonolysis the cyclobutane ring with zinc acetate and $\mathrm{BF}_{3} \cdot \mathrm{OEt}_{2}$ in acetic anhydride formed enol acetate. The diol formed by reduction with DIBAL-H. In the following, enol phosphate was produced with $\alpha$-iodoketone in the presence of $\mathrm{EtMgBr}$ and diethyl chlorophosphonate. The resulting intermediate was cyclized through Evans $\left(\mathrm{ZnBr}_{2}, \mathrm{MgSO}_{4}\right)$, and finally, $\Delta^{9}$-THC has been produced (Fig. 6).

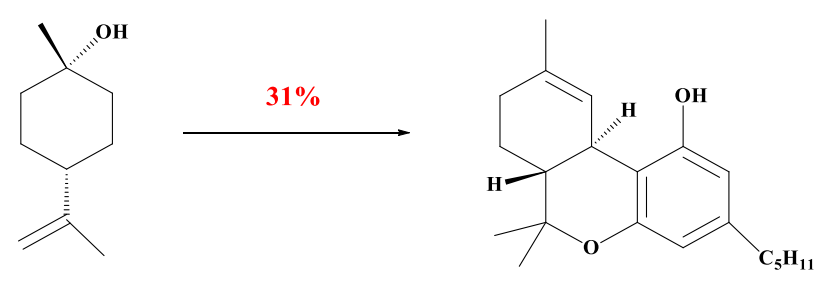

Fig. 4 Reagents: Olivetol (5-pentylbenzene-1, 3-diol), $\mathrm{BF}_{3} \cdot \mathrm{OEt}_{2}$, $\mathrm{MgSO}_{4}$
Trost et al. synthesized $\Delta^{9}$-THC via Mo-catalyzed asymmetric allylic alkylation reaction [67]. Allyl alcohol was prepared in four steps. Dimethyl olvitol with dry DMF formed intended aldehyde in $83 \%$ yield. Allylic alcohol was prepared through Horner-Wadsworth-Emmond reaction in the presence of sodium triethylphosphonoacetate and DIBAL-H reduction in $97 \%$ yield. In the following, allylic carbonate with sodium dimethyl malonate and $\left[\mathrm{Mo}(\mathrm{CO})_{3} \mathrm{C}_{7} \mathrm{H}_{8}\right]$ in the presence of chiral ligand formed branched product in 95\% yield. They have prepared the intended acid from the branched product under classical conditions in $97 \%$. Methyl esters formed by dianion of acid alkylation with iodide and provided anti- and syn-cyclohexene compounds by Grubb's carbene catalyst. This syn compound was recycled to anti with $\mathrm{NaOMe}$ in $\mathrm{MeOH}$. The cyclized ester formed tertiary alcohol with MeLi in 92\% yield. Finally, mono-demethylation tertiary alcohol with NaSEt in the presence of $\mathrm{ZnBr}_{2}$, $\mathrm{MgSO}_{4}$, and de-protection of this product through NaSEt in dimethylformamide provided (-)- $\Delta^{9}$-trans-THC in $61 \%$ yield (Fig. 7).

Minuti et al. used high pressure as the activating method of the Diels-Alder reactions for obtaining $\Delta^{9}$-cis- and $\Delta^{9}$ trans-THC [68]. In this method, Diels-Alder reaction was done between 3-methyl-1-(alkoxy/alkyl-substituted phenyl) buta-1,3-dienes and But-3-en-2-one(methyl vinyl ketone) under high-pressure condition ( $9 \mathrm{kbar}$ ) and then trans and cis-cyclohexenyl-benzene cycloadducts were prepared. The cis-cyclohexenyl-benzene cycloadducts produced by Diels-Alder reaction under Grignard conditions and formed pyran ring and then $\Delta^{9}$-cis-THC in $70 \%$ yield. $\Delta^{9}$-trans-THC was provided through Kobayashi and Trost methods in the presence of trans-cyclohexenyl-benzene cycloadducts by methanolic sodium methoxide, NaSMe and DMF (Fig. 8) $[66,67]$.

Xie et al. reported total syntheses of $(-)-\Delta^{9}$ tetrahydrocannabinol by using ruthenium-catalyzed [69]. 1,4-Cyclohexene di-one-mono-ethylene acetal was iodinated at room temperature and cyclic $\alpha$-iodo enone was provided in $84 \%$ yield. $\alpha$-Arylated cyclic enone was prepared by the Suzuki-Miyaura cross-coupling of cyclic $\alpha$-iodoenone with

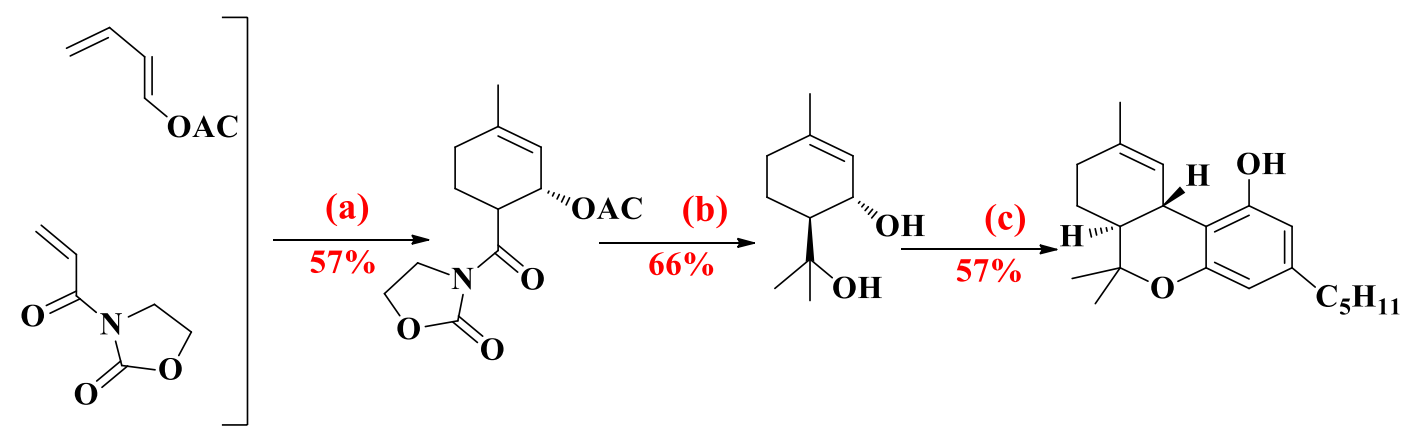

Fig. 5 Reagents: a, b LiOBn, $\mathrm{MeMgBr}$ and $\mathbf{c} p$-TSA, Olivetol, $\mathrm{ZnBr}_{2}$ 
Fig. 6 Reagents: a $\mathrm{Zn}(\mathrm{OAc})_{2}$, $\mathrm{BF}_{3} \cdot \mathrm{OEt}_{2}, \mathrm{AC}_{2} \mathrm{O} ; \mathbf{b} \mathrm{Pd}(\mathrm{OAc})_{2}$, DPPE, $\mathrm{Bu}_{3} \mathrm{SnOMe}$; $\mathbf{c}$ DIBAL$\mathrm{H} ; \mathbf{d}$ PCC; $\mathrm{I}_{2}, \mathrm{C}_{5} \mathrm{H}_{5} \mathrm{~N} ; \mathbf{f}$ $\mathrm{Ar}_{2} \mathrm{Cu}(\mathrm{CN}) \mathrm{Li}_{2} ; \mathbf{g}$ 1. EtMgBr. 2. $\mathrm{ClP}(\mathrm{O})(\mathrm{OEt})_{2} ; \mathbf{h}$ NaSEt and $\mathbf{i}$ $\mathrm{ZnBr}_{2}, \mathrm{MgSO}_{2}$

Fig. 7 Reagents: a $(\mathrm{MeO})_{2} \mathrm{SO}_{2}$, $\mathrm{K}_{2} \mathrm{CO}_{3}$, acetone; b BuLi, DMF, THF; c 1. (EtO) ${ }_{2} \mathrm{P}(\mathrm{O})$ $\mathrm{CH}_{2} \mathrm{CO}_{2} \mathrm{Et}$, tetrahydrofuran (THF). 2. DIBAL-H, ether; d BuLi, THF, acrylaldehyde; e $\mathrm{PdCL}_{2}\left(\mathrm{CH}_{3} \mathrm{CN}\right)_{2}, \mathrm{BuLi}, \mathrm{CO}_{2}$, THF; f BuLi, $\mathrm{ClCO}_{2} \mathrm{CH}_{3}$, ether; $\mathbf{g}$ ligand $N, N^{\prime}-((1 \mathrm{R}, 2 \mathrm{~S})-$ cyclohexane-1,2-diyl)dipicolinamide, $\left[\mathrm{MO}(\mathrm{CO})_{3} \mathrm{C}_{7} \mathrm{H}_{8}\right]$, sodium dimethyl malonate; $\mathbf{h}$ 1. $\mathrm{NaOH}$. 2. $\mathrm{HCl}$. 3. $160{ }^{\circ} \mathrm{C}$; i 4-iodo-2-methylbut-1ene, THF; j 1. (MeO) ${ }_{2} \mathrm{SO}_{2}$, $\mathrm{K}_{2} \mathrm{CO}_{3}$. 2. Grubbs catalyst; $\mathbf{k}$ ether, $-78{ }^{\circ} \mathrm{C} ; \mathbf{1}$ NaSEt, DMF, $140{ }^{\circ} \mathrm{C}$ and $\mathbf{m ~} 1 . \mathrm{ZnBr}_{2}$, $\mathrm{MgSO}_{4}, \mathrm{CH}_{2} \mathrm{Cl}_{2}$. 2. NaSEt, DMF, $140{ }^{\circ} \mathrm{C}$

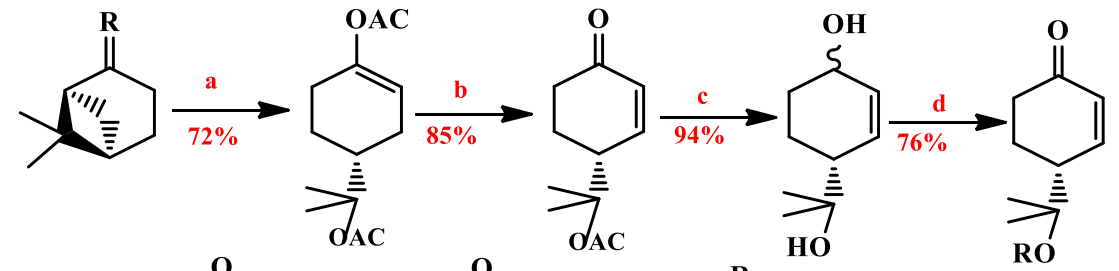

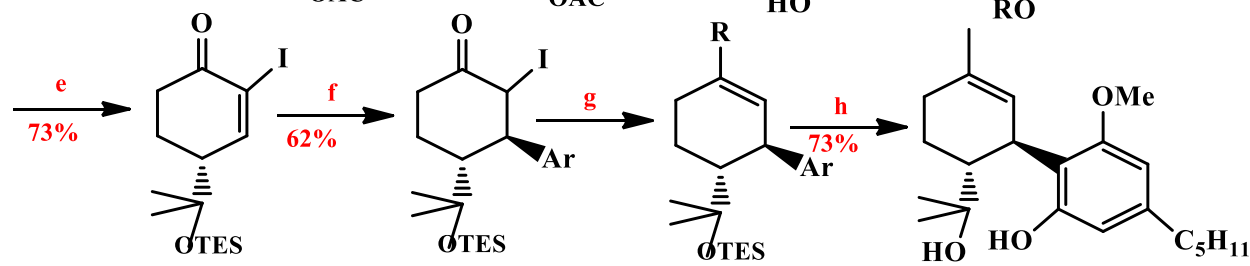<smiles>[R2]Oc1cc(CCCC)cc2c1[C@@H]1C=C(C)CC[C@H]1C(C)(C)O2</smiles>

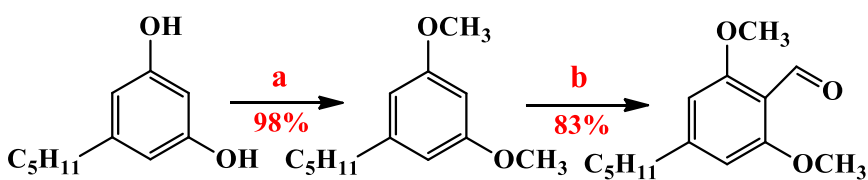

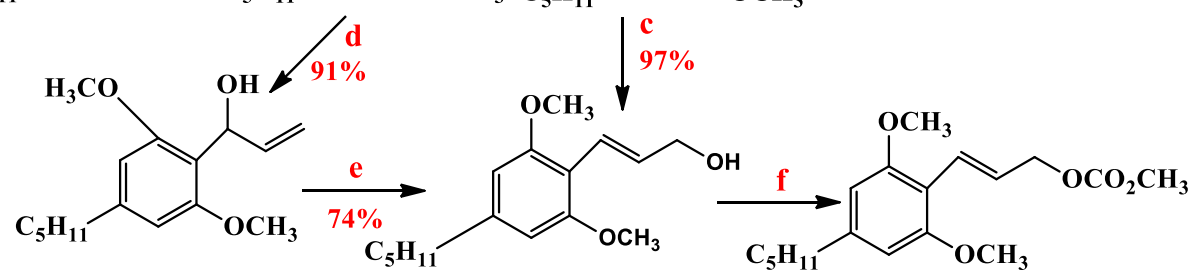

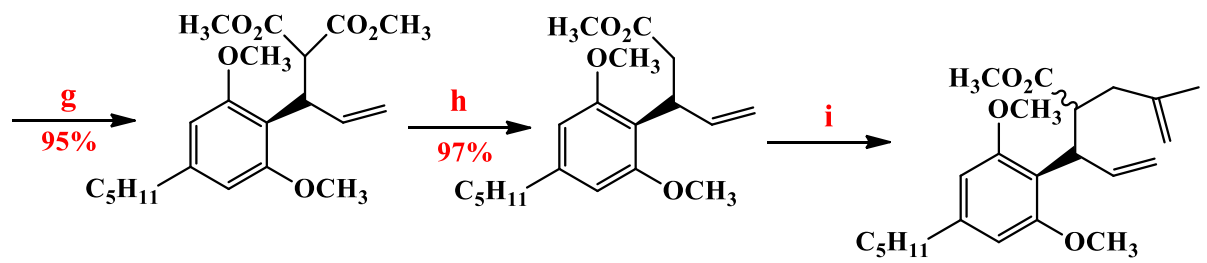

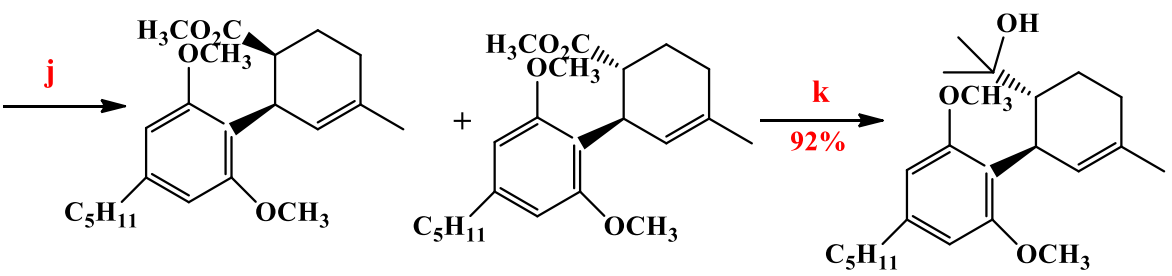

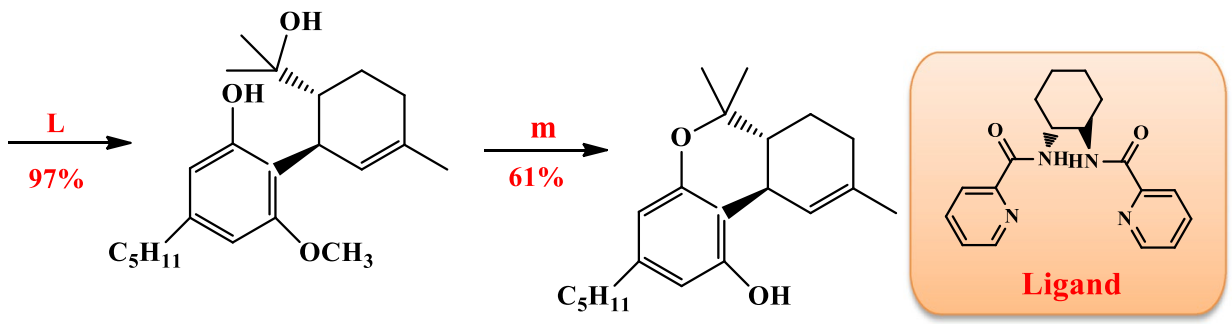




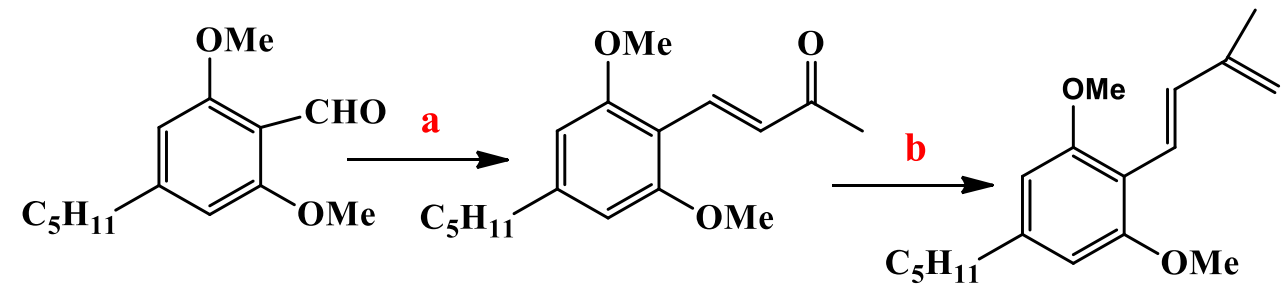

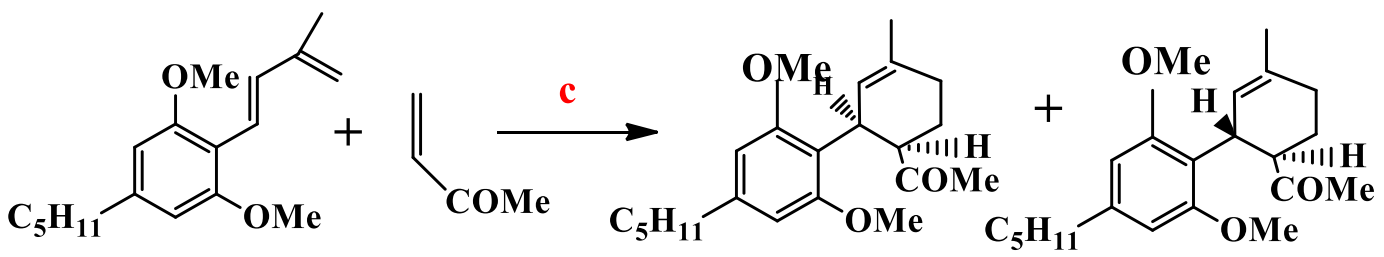

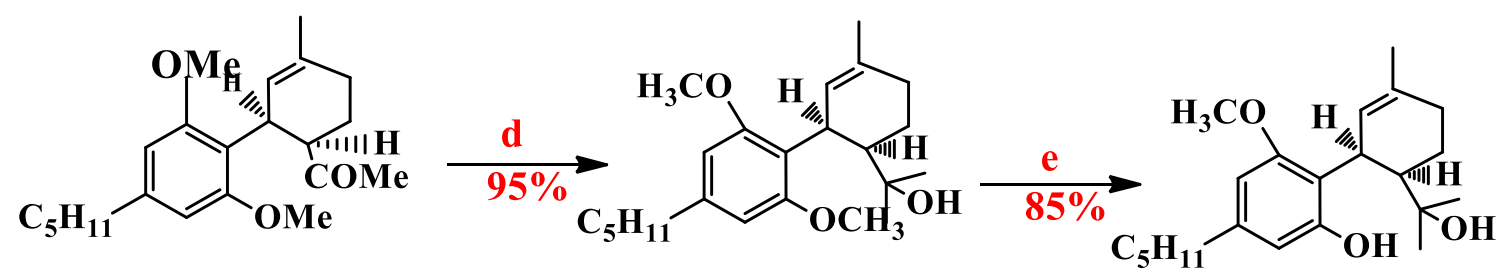

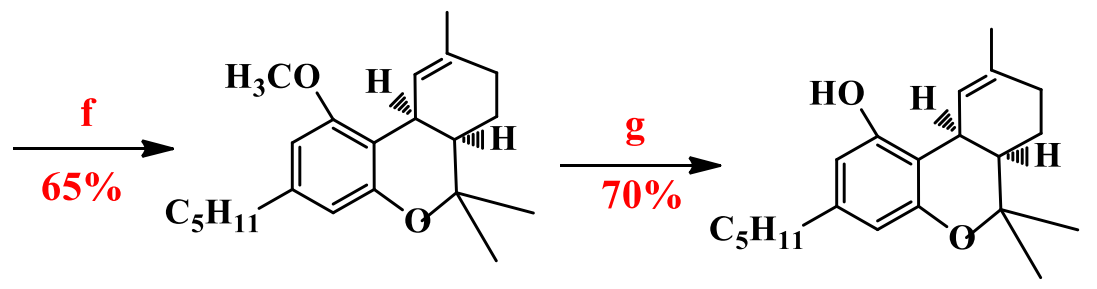

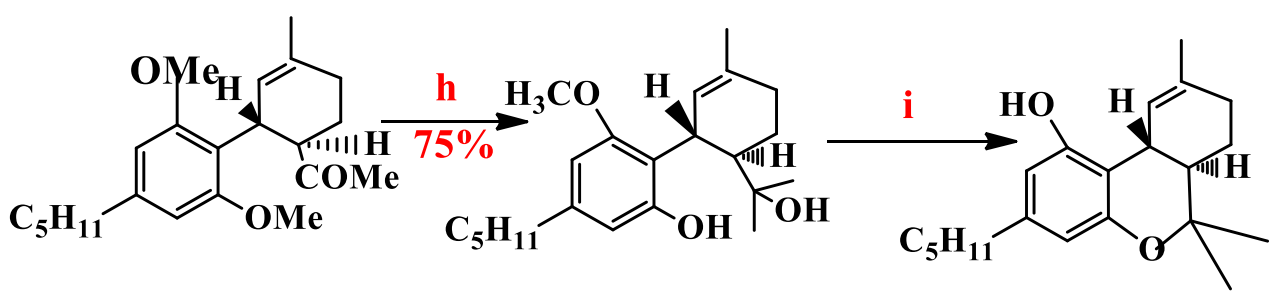

Fig. 8 Reagents: a $\mathrm{CH}_{3} \mathrm{COCH}_{3}, \mathrm{NaOH}$; b $(\mathrm{Ph})_{3} \mathrm{P}=\mathrm{CH}_{2}$, THF; c Diels-Alder reaction, 9 kbar; d MeMgBr, PhMe; e NaSMe, DMF; f TsOH, benzene; g NaSMe, DMF; h 1. MeMgBr, PhMe. 2. NaSMe, DMF and i Refs. [38, 39]

arylboronic acid in $93 \%$ yield. $\alpha$-Arylated cyclic enone was hydrogenated on $\mathrm{Pd} / \mathrm{C}$ and generated cyclic ketone in $90 \%$ yield and then under $\mathrm{MeOCH}_{2} \mathrm{PPh}_{3} \mathrm{Cl}$ and $\mathrm{BuLi}$ intended olefin was obtained in $90 \%$ yield. This olefin is produced in four steps: aqueous $\mathrm{AcOH}$ solution, oxidation with the Jones reagent, esterification and isomerization with $\mathrm{NaOMe}$ giving the intended ester in $76 \%$ yield. This ester reacted with $\mathrm{MeMgBr}$ and provided chiral diol in $91 \%$ yield. Finally, the produced diol promoted the SNAr reaction in basic conditions and $\Delta^{9}$-THC obtained in presence of $\mathrm{ZnCl}_{2} / \mathrm{HCl}$, K-t-pentoxide in $80 \%$ yield (Fig. 9).

Leahy et al. have used a chemoenzymatic synthesis of $\Delta^{9}$-THC and cannabidiol [70]. $\alpha, \beta$-Unsaturated enone was prepared by methylation and formylation of olivetol. The allyl alcohol resulted from enone in two routes: (1) Corey-Bakshi-Shibata oxazaborolidine (2) reduction of $\alpha$, $\beta$-unsaturated enone with sodium borohydride, acylation with vinyl butyrate acylation in presence of Savinase $12 \mathrm{~T}$. 
Fig. 9 Reagents: $\mathrm{I}_{2}, \mathrm{~K}_{2} \mathrm{CO}_{3}$, DMAP, THF; b $\mathrm{Pd}\left(\mathrm{PPh}_{3}\right)_{4}$,

LiCL, $\mathrm{Na}_{2} \mathrm{CO}_{3}$, DME;

c $\mathrm{Pd} / \mathrm{C}, \mathrm{EtOH}$; d BuLi,

$\mathrm{MeOCH}_{2} \mathrm{PPh}_{3} \mathrm{Cl}$, THF; $\mathbf{e} 1$.

$\mathrm{HOAc} / \mathrm{H}_{2} \mathrm{O}$. 2. Jones reagent, acetone. 3. MeI, $\mathrm{K}_{2} \mathrm{CO}_{3}$, DMF.

4. $\mathrm{NaOMe}, \mathrm{MeOH}$; $\mathrm{C}_{3} \mathrm{MgBr}$,

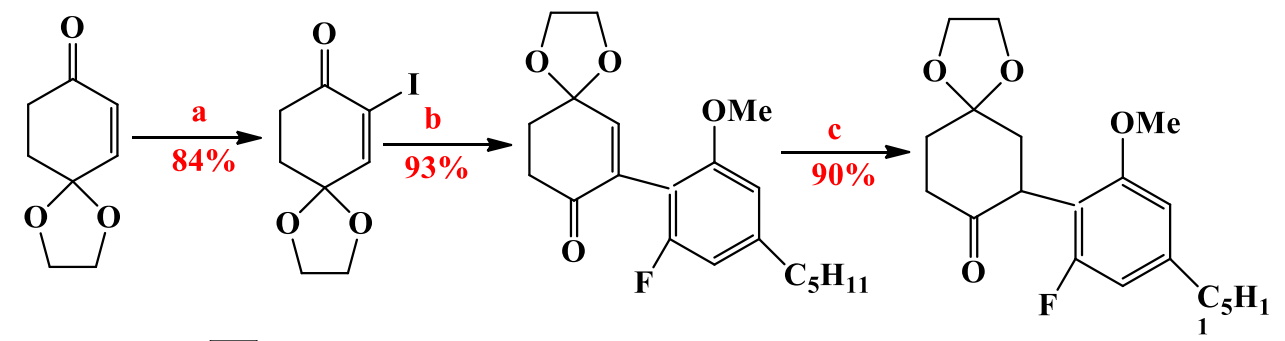
THF; $\mathbf{g ~ N a H}, \mathrm{Et}_{2} \mathrm{NCH}_{2} \mathrm{CH}_{2} \mathrm{SH}$

$\mathrm{DMF}$ and $\mathbf{h} 1 . \mathrm{ZnCL}_{2} / \mathrm{HCL}$,

AcOH. 2. K-t-pentoxide,

benzene<smiles>CCCCCC=C1CCC2(C[C@@H]1c1c(F)cc(CCCCCC)cc1OC)OCCO2</smiles>

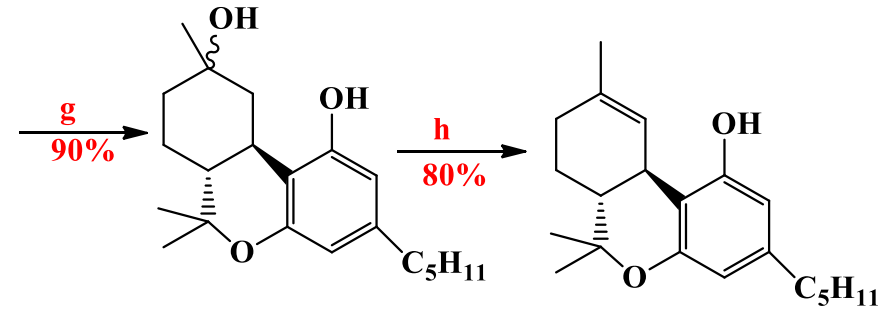

Esterification of the obtained ketone and cyclization with Grubbs' second-generation catalyst produced cyclohexene. Finally, cyclohexene with methylmagnesium iodide through Lewis acid-mediated cyclization formed (-)-trans- $\Delta^{9}$-THC in 57\% yield (Fig. 10).

Antoniotti et al. found an efficient method for $\Delta^{9}$-orthoTHC by two catalytic steps (Fig. 11) [71]. They used two catalysts for oxidation and cyclization of alcohols: (1) Au nanoparticle-catalysis, (2) Ti-MMT-catalysis (acid catalysis). After protonation/dehydration the allylic cation was obtained and then combined with olivetol and gave $\Delta^{9}$ ortho-tetrahydrocannabinol in $77 \%$ yield (Fig. 12).
Lupton and Ametovski presented a new way to synthesize $\Delta^{9}$-THC by $N$-heterocyclic carbene (NHC) catalysis [72]. Cinnamoyl fluorides and cyclobutane in the presence of NHC catalyst resulted in cycloxyl $\beta$-lactone in a $45 \%$ yield. cis- and trans-cyclohexenes were formed from lactone in the presence of KCN oxidant, IBX and Krapcho decarboxylation reaction. Trost and Dogra had reported the conversion method of the cis-to-trans mixture [67]. Finally, according to the methods performed by Carreira and Petrzilka [73, 74], the authors were obtained $\Delta^{9}$-THC in $89 \%$ yield (Fig. 13).

Recently synthesis of $\Delta^{9}$-THC was reported by Carreira et al. $\alpha$-Allylation of the aldehyde with allyl alcohol by
Fig. 10 Reagents: a $1 . \mathrm{Me}_{2} \mathrm{SO}_{4}$, $\mathrm{K}_{2} \mathrm{CO}_{3}, 80^{\circ} \mathrm{C}$. 2. S-BuLi, DMF, $-78^{\circ} \mathrm{C}$ to rt. 3 . NaOH, $\mathrm{Me}_{2} \mathrm{CO}, 60^{\circ} \mathrm{C} ; \mathbf{b} 1 . \mathrm{NaBH}_{4} .2$. Savinase $12 \mathrm{~T}$, vinyl butyrate. 3. $\mathrm{NaOH}, \mathrm{H}_{2} \mathrm{O}$, EtOH, reflax; c Oxazaborolidine, $\mathrm{BH}_{3} \mathrm{THF}$, toluene, $-78^{\circ} \mathrm{C} ; \mathbf{d} 1$. DCC, DMAP. 2. KHMDS, $-78^{\circ} \mathrm{C} .3$. TMSCL, py, $-78^{\circ} \mathrm{C}$ to rt; $\mathbf{e} 1$. $\mathrm{Me}_{3} \mathrm{SiCHN}_{2}$. 2. Grubbs II and $\mathbf{f}$ 1. MeMgI. 2. $\mathrm{ZnBr}_{2}$

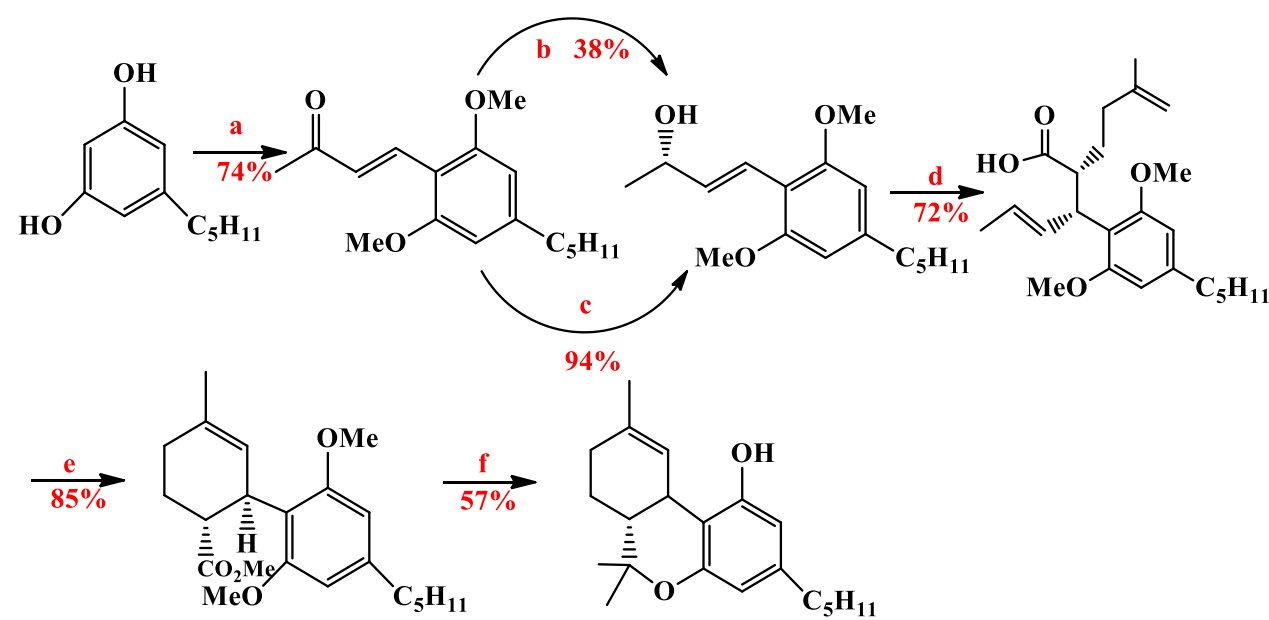


Fig. 11 Reagents: a Au NPs catalysis, $\mathrm{O}_{2}$; b Ti/MMT catalysis; $\mathbf{c} \mathrm{H}^{+},-\mathrm{H}_{2} \mathrm{O}$; d Olivetol (5-pentylbenzene-1,3-diol) and e Hydroalkoxylation
Fig. 12 Chemistry design for the synthesis of $\Delta^{9}$-ortho-THC

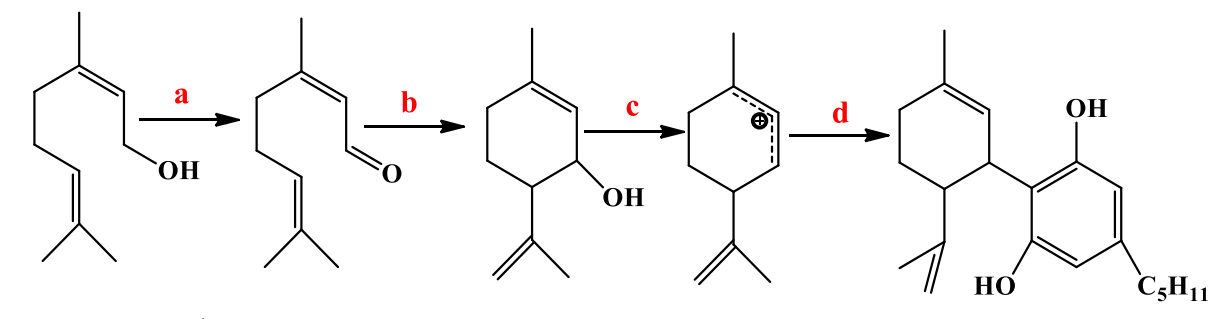<smiles>CCCCCCCCCCCCCCCCCCCCCCCCC</smiles>

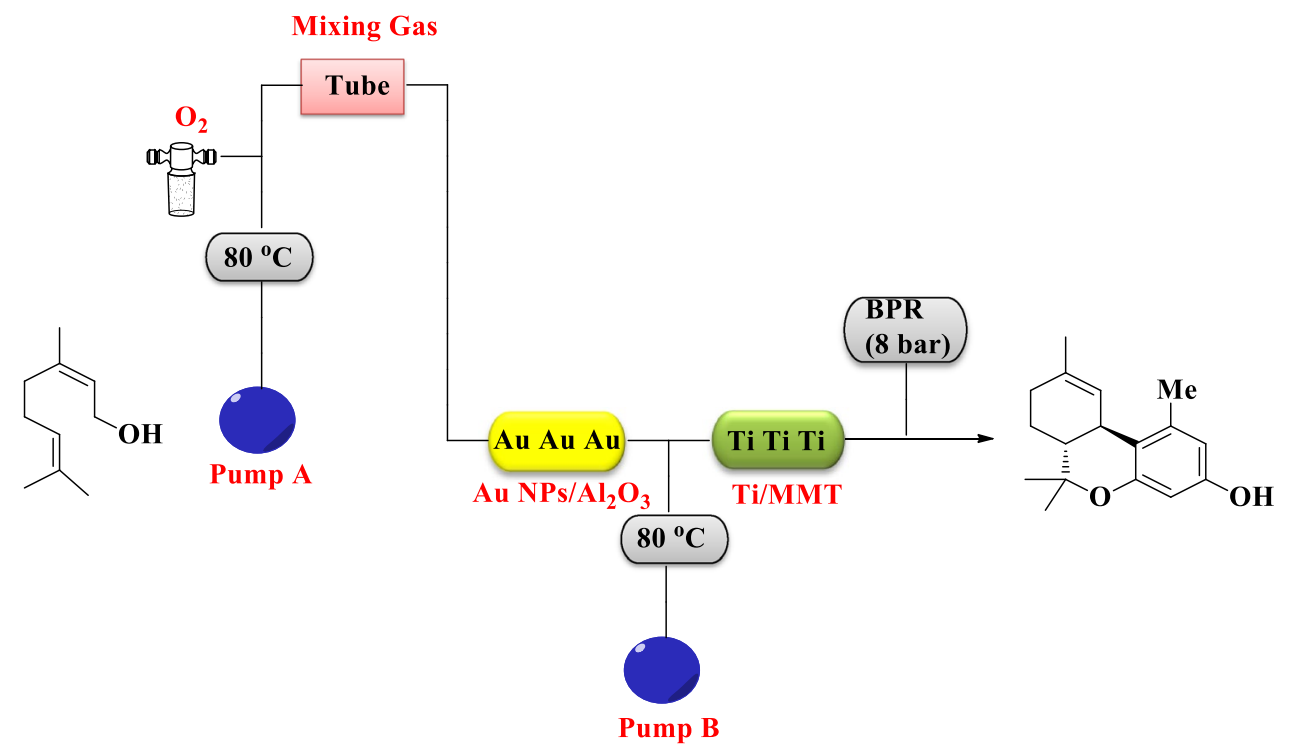

dual catalytic (Ir-(phosphoramidite, olefin)-catalyst and proline-derived Hayashi-Jorgensen catalyst (A4)) was produced all of four $\gamma, \delta$-unsaturated aldehyde in $60 \%, 55 \%$, $54 \%$, and $62 \%$ yields [75]. Then cyclohexanecarbaldehydes formed from Grubbs second-generation catalyst and methyl esters were produced by Pinnick oxidation. Finally, $\Delta^{9}$-THC was formed by the formation of tertiary alcohol and double methyl ether deprotection and intramolecular etherification in 34\%, 21\%, 25\%, and 36\% yields (Fig. 14) [73].

Keasling et al. used the biosynthesis method for the synthesis of $\Delta^{9}$-tetrahydrocannabinol. They produced cannabigerolic acid (CBGA) by geranyl pyrophosphate (GPP) and olivetolic acid. Cannabigerolic acid was converted to tetrahydrocannabinolic acid (THCA) by the cannabinoid synthases THCAS. $\Delta^{9}$-THC was produced after THCA decarboxylate by heat (Fig. 15) [73].

Verbeck et al. used the chemical method for produced $\Delta^{9}$-THC by the acid-catalyzed cannabidiol reaction with the addition of the three acids such as battery acid, muriatic acid and vinegar (Fig. 16) [76].

\section{Synthesis of cannabidiol (CBD)}

Various synthetic methods have been reported for CBD. In 1964, Mechoulam and Gaoni presented the first synthesis of cannabidiol [77]. In this study, their methods include the addition of geranial to lithiation of olivetol dimethyl ether which formed allyl alcohol. Tosylation of allyl alcohol with $p$-toluenesulfonyl chloride led to the cyclization, and eventually demethylation with methyl magnesium iodide. This synthesis had its drawbacks, including the production of the racemic -CBD and its low yield. In 1965, Petrzilka et al. presented a stereoselective synthesis method for (-)-CBD. The (-)-cannabidiol can be obtained through olivetol with 4-isopropenyl-1-methyl-2-cyclohexene-1-ol in the presence of $N, N$-dimethylformamide (DMF) [78, 79]. In this method, 
Fig. 13 Reagents: a DAST, $\mathrm{CH}_{2} \mathrm{Cl}_{2} ; \mathbf{b} \mathrm{NHC}, \mathrm{DMF} / \mathrm{THF}$; c $1 . \mathrm{KCN}, \mathrm{MeOH}$. 2. IBX, EtOAc, $80^{\circ} \mathrm{C} ; \mathbf{d} 1 . \mathrm{LiCl}, \mathrm{H}_{2} \mathrm{O}$, DMSO, $170{ }^{\circ} \mathrm{C}$; e $\mathrm{NaOMe}$, $\mathrm{MeOH}, 50{ }^{\circ} \mathrm{C} ; \mathbf{f} 1 . \mathrm{MeMgI}$, $\mathrm{Et}_{2} \mathrm{O}, 160^{\circ} \mathrm{C} .2 . \mathrm{ZnBr}_{2}, \mathrm{MgSO}_{4}$, $\mathrm{CH}_{2} \mathrm{Cl}_{2}$ and $\mathbf{g ~} 1 . \mathrm{ZnCl}_{2}, \mathrm{HCl}$, $\mathrm{CH}_{2} \mathrm{Cl}_{2}$. 2. $\mathrm{KOC}_{5} \mathrm{H}_{11}$, toluene

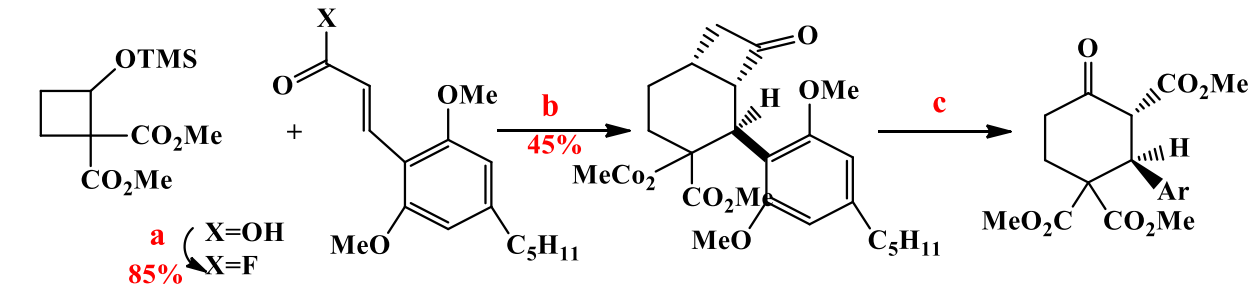

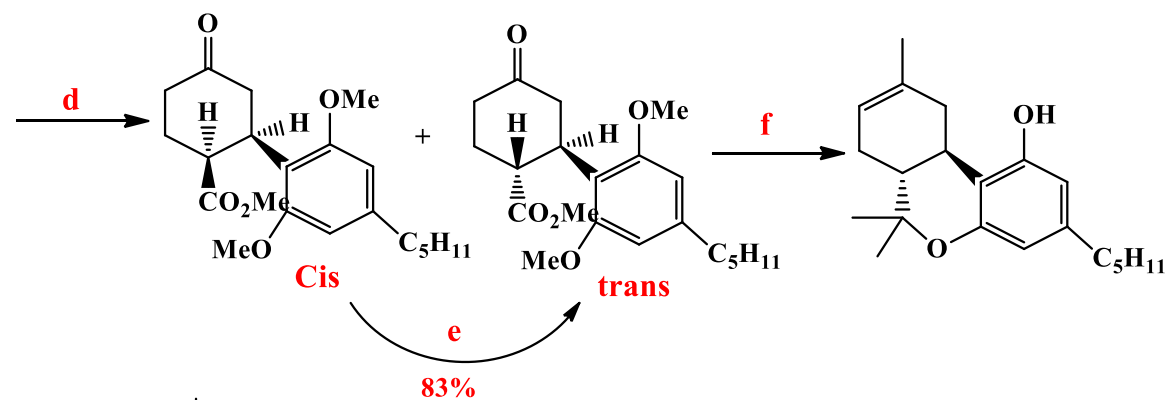<smiles>CCCCCCCCCCCCCCCCCCCCCCCCC</smiles>

the yield is a mixture of three products: (-)-CBD: $25 \%$, abnormal cannabidiol: 35\%, (-)-2,4-disubstituted olivetol: 5\% (Fig. 17).

The remaining problem is the formation of abnormal CBD [(-)-4-(3-3,4-trans-p-menthadien-(1,8)-yl)-olivetol] as a by-product, and this synthetic way is not practical value. Beak et al. have modified this procedure in weak acid conditions. They used boron trifluoride etherate in basic alumina $\left(\mathrm{BF}_{3} \cdot \mathrm{OEt}_{2} / \mathrm{Al}_{2} \mathrm{O}_{3}\right)$ as a reagent in reaction olivetol with (+)-cis/trans-p-mentha-2,8-dien-1-ol, which prevented the formation of abnormal cannabidiol. The major product was obtained at $44 \%$ yield [80].

In 1966, Korte et al. and Kochi et al. suggested a new synthetic approach. This method considers two steps: first, $[4+2]$ cycloaddition of (4) and (3) as diene and dienophile which allowing the formation of cis/trans product (5). Second, a Wittig reaction gives the diastereoisomeric cis/trans (6), which produced ( \pm )-CBD in $16 \%$ low yield after the deportation of methyl groups [81-83]. Kochi's method differed just in the formation of (3). They procured it by a Grignard reaction and dehydration with (1) [84] (Fig. 18).

Pinnick and coworker used Diels-Alder procedures from the Claisen rearrangement reaction for prepare $( \pm)$-CBD. They have synthesized (3) by Diels-Alder reaction in the presence of (1) and methyl methacrylate (2) with DIBAL reduction. Then (5) is formed by Wittig reaction in the presence of (4) and cyclic dihydropyran intermediate. A Wittig reaction of (6) and deprotection of phenyl hydroxyl groups produce (7). Deletion of the methyl ether group of $( \pm)-(7)$ produces ( \pm )-CBD (Fig. 19) [85].

Burdick et al. used Friedel-Craft reactions for ethyl cannabidiolate (2) and (1) in the presence of scandium triflate as a catalyst. $\mathrm{Sc}(\mathrm{OTf})_{3}$ has some benefits. For example, it is stable and works in the presence of aqueous solutions (Fig. 20) [86].

Dialer et al. used protecting groups and they provided dibromide (2) in $82 \%$ yield. Then, Friedel-Crafts alkylation of dibromide intermediate (2) and (3) under acid condition produced the (4) in (90-99\%) yield. Finally, reductive debromination of (4) provided (-)-CBD in $78 \%$ yield (Fig. 21) [87].

Another useful strategy for the synthesis of cannabidiol is reported with Kobayashi et al.. In this synthesis, cyclohexenylmonoacetate reacted with zinc reagent and $\mathrm{NiCl}_{2}$ $\left(\mathrm{PPh}_{3}\right)_{2}$ as a catalyst and ligand tetramethylethylenediamine (TMEDA) as a ligand formed (1R, 4R)-p-Mentha-2, 8-dien1-ol (1). The compound (2) was produced by Jones oxidation and iodination from compound (1). Then compound (3) formed in the presence of boron trifluoride diethyl etherate. This enol phosphate (4) was obtained via the magnesium enolate and using a Grignard reagent through $\mathrm{ClP}(\mathrm{O})(\mathrm{OEt})_{2}$. The mixture (5) was formed under Ni-catalyzed reaction with Kumada coupling by methylmagnesium chloride. The demethylation mixture (5) led to the production of (-)-CBD with $\mathrm{SN}_{2}$-type in good yield (Fig. 22) [88-92]. Kobayashi method is less facile than the one-step synthesis of beak. 
Fig. 14 Reagents: a $\left[\mathrm{Ir}\left(\mathrm{C}_{8} \mathrm{H}_{12}\right)\right.$ $\mathrm{Cl}_{2}$, (R)-or(s) L, (R)-or (S)A4, $\mathrm{Zn}(\mathrm{OTf})_{2}, 1,2$ DCE, rt, $20 \mathrm{~h}$; b Grubbs II cat. $92 \%$ (S,S), 87\% (R,S), $90 \%$ (S,R), $85 \%$ (R,R); c sodium chlorite, sodium dihydrogen phosphate, 2-methyl2-butene, $\mathrm{tBuOH} / \mathrm{H}_{2} \mathrm{O}, 258 \mathrm{C}$; d $\mathrm{Me}_{3} \mathrm{SiCHN}_{2}, \mathrm{C}_{6} \mathrm{H}_{6} / \mathrm{MeOH}, 66 \%$ (S,S), 60\% (R,S), $61 \%$ (S,R), $65 \%(\mathrm{R}, \mathrm{R}) ;$ e MeMgI, $\mathrm{Et}_{2} \mathrm{O}$, pressure to $150 \mathrm{~mm} \mathrm{Hg} ; \mathrm{ZnBr}_{2} /$ $\mathrm{CH}_{2} \mathrm{Cl}_{2}, 258 \mathrm{C}, 34 \%(\mathrm{~S}, \mathrm{~S}), 21 \%$ (R,S), 25\% (S,R), 36\%(R,R)
Fig. 15 Reagents: a CsPT4; b THCAS and $\mathbf{c}$ heat $(\Delta T)$

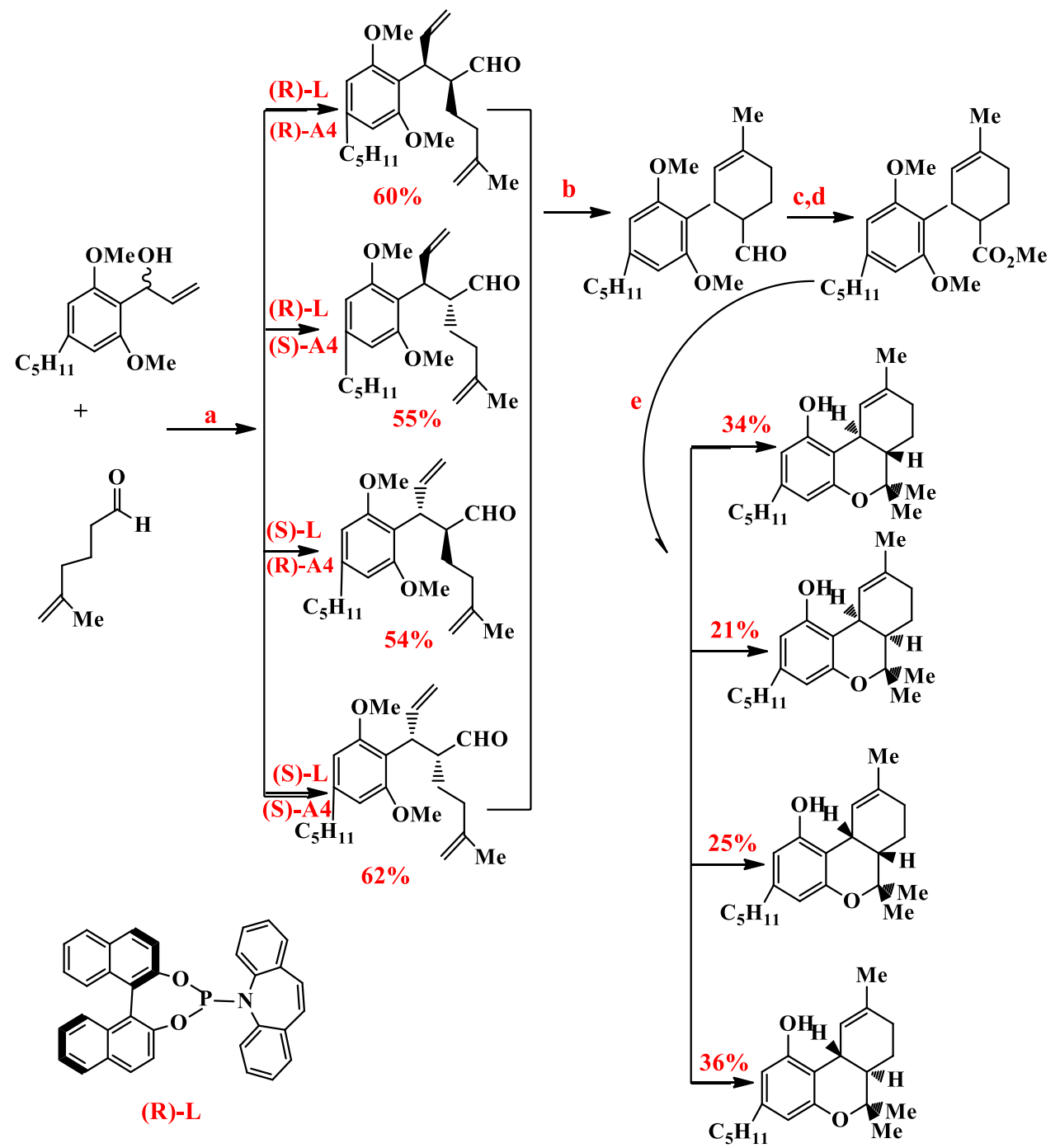

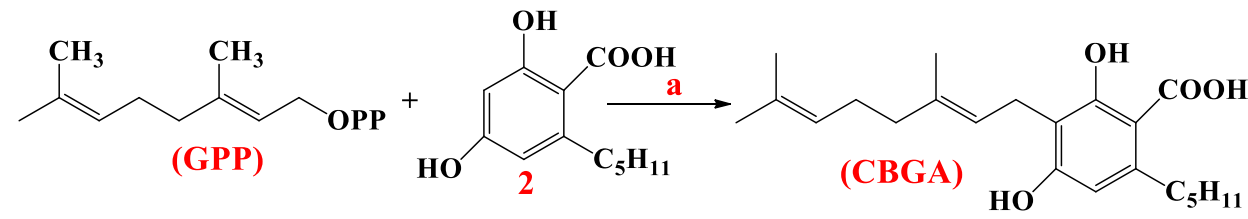

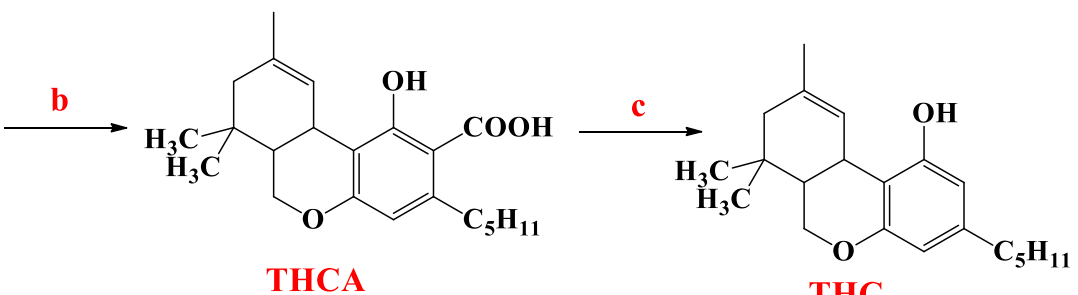

Teske et al. used a direct approach to the synthesis of CBD. In other words, olivetol was reacted with the diol (2) using the optimized Friedel-Crafts alkylation, and the triol (3) was produced in 73\% yield. The mesylation of triol
(3) with $\mathrm{Et}_{3} \mathrm{~N}$ provided the elimination of the isopropenyl group. Then, the aromatic mesylate groups were removed with MeLi and ( \pm )-CBD was produced in satisfactory yield (Fig. 23) [93]. 
Fig. 16 Isomerization reaction of cannabidiol to $\Delta^{9}$ tetrahydrocannabinol
Fig. 17 Reagents: $\mathrm{Me}_{2} \mathrm{NCH}$ $\left(\mathrm{OCH}_{2} \mathrm{C}\left(\mathrm{CH}_{3}\right)_{3}\right)_{2}, \mathrm{CH}_{2} \mathrm{Cl}_{2}$, rt, $63 \mathrm{~h}$

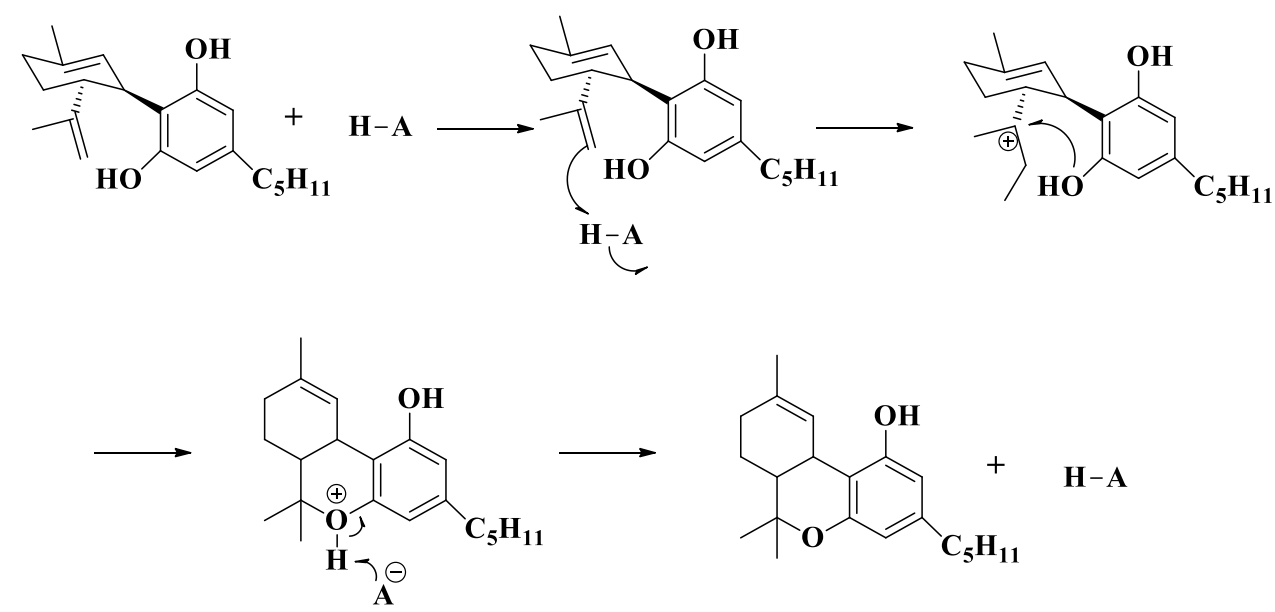

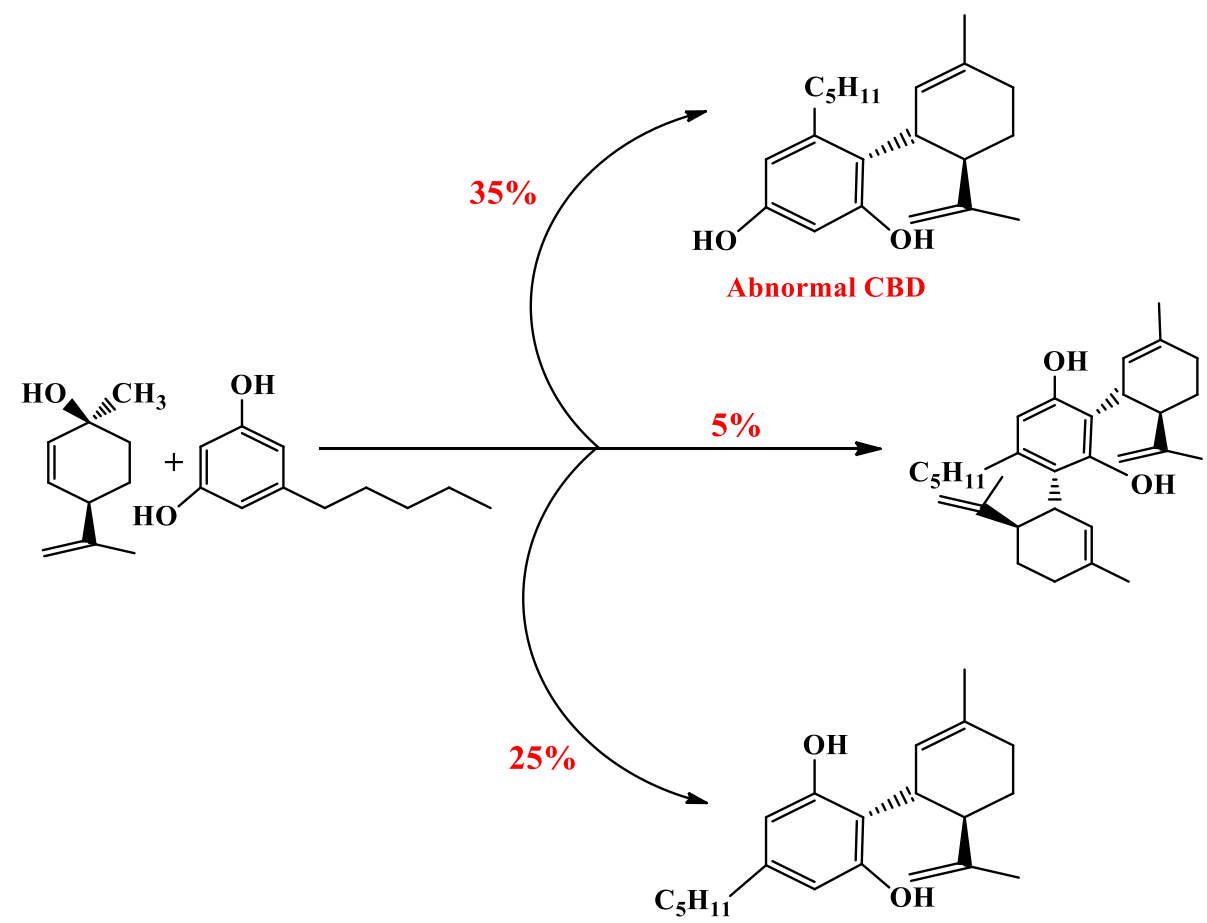

Ballerini et al. reported the synthetic route for CBD under a high-pressure Diels-Alder approach to hydroxysubstituted 6a-cyano-tetrahydro- $6 H$-benzo[ $c]$ chromen6-ones. In this approach, 3-cyanocoumarin hydroxy dienophile reacted with isoprene $([4+2]$ cycloaddition $)$ in mild reaction with $11 \mathrm{kbar}$ pressure and produced tetrahydro-6H-benzo[ $c]$ chromen-6-ones in high yields. Decyanation reaction of the cycloadducts, 6a-cyano-tetrahydro- $6 H$-benzo[ $c]$ chromen-6-ones in aqueous solution of $\mathrm{NaHCO}_{3}$ formed cis-1-hydroxy-9-methyl-3-pentyl6a,7,10,10atetrahydro-benzo[c]chromen-6-one. (Fig. 24) [94]. The reaction of cis-1-hydroxy-9-methyl-3-pentyl6a,7,10,10atetrahydro-benzo[c]chromen-6-one with
$\mathrm{CH}_{3} \mathrm{MgI}$ gave the triol compound and it's dehydrated with thionyl chloride in pyridine gave CBD [95].

Gianluca Brufola et al. prepared 3-cyano-hydroxy-substituted-coumarins by Knoevenagel condensation between salicylic aldehydes and malonitrile [96], but in this synthetic method, Ballerini et al. proposed a new environmentally friendly synthetic route for $\Delta^{9}$-cis-cannabidiol.

Leahy et al. have reported a synthetic method for CBD on a large scale with high enantiopurity [70]. In this synthesis, $\alpha, \beta$-unsaturated enone was prepared from the formylation of olivetol and aldol process with acetone. They used two methods to prepare allyl alcohol: (1) CBS oxazaborolidine, (2) an enzymatic approach. In this method, (2) reduction 
<smiles>C=CC(C)=O</smiles>

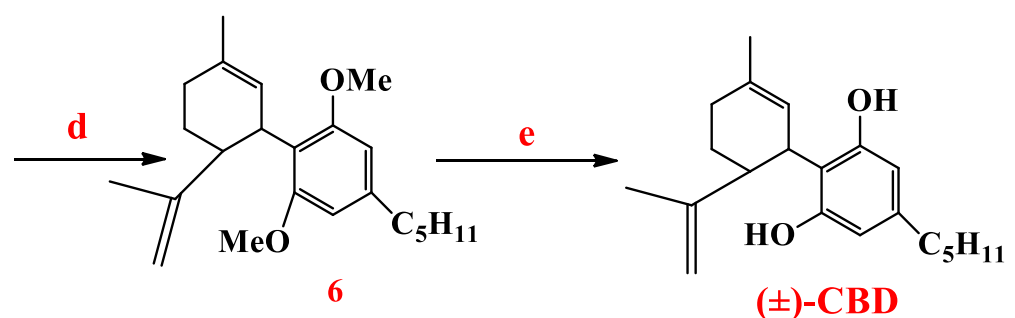

Fig. 18 Reagents: a acetone, $\mathrm{NaOH}, 20$ h, 80\%; b 1. $\mathrm{Ph}_{3} \mathrm{PCH}_{3} \mathrm{Br}$, BuLi, THF, 3 h. 2.15 h, reflux, 79\%; c vinyl ketone, hydroquione, toluene, $64 \%$; $\mathbf{d ~} \mathrm{Ph}_{3} \mathrm{PCH}_{3} \mathrm{Br}$, BuLi, THF, $3 \mathrm{~h}, 78 \%$ and e $1 . \mathrm{CH}_{3} \mathrm{I}, \mathrm{Mg}, \mathrm{Et}_{2} \mathrm{O}, 130{ }^{\circ} \mathrm{C}$. 2. $165-170{ }^{\circ} \mathrm{C}, 20 \mathrm{~min}, 50 \%$

Fig. 19 Reagents: a $1.200^{\circ} \mathrm{C}$, $\mathrm{C}_{6} \mathrm{H}_{6}, 2 \mathrm{~h}, 67 \%$. 2. DIBAL, $\mathrm{C}_{6} \mathrm{H}_{6},-78{ }^{\circ} \mathrm{C} ; \mathbf{b ~} \mathrm{Ph}_{3} \mathrm{PCH}_{3} \mathrm{Br}$, $\mathrm{NaH}$, DMSO; c (4); $\mathbf{d ~} \mathrm{CH}_{2} \mathrm{Cl}_{2}$, $48 \mathrm{~h}, 94 \%$ and e $1 . \mathrm{Ph}_{3} \mathrm{PCH}_{3} \mathrm{Br}$, THF, $n$-BuLi, 3 h, r.t. 2. (6), THF, 6 h, reflux, $80 \%$

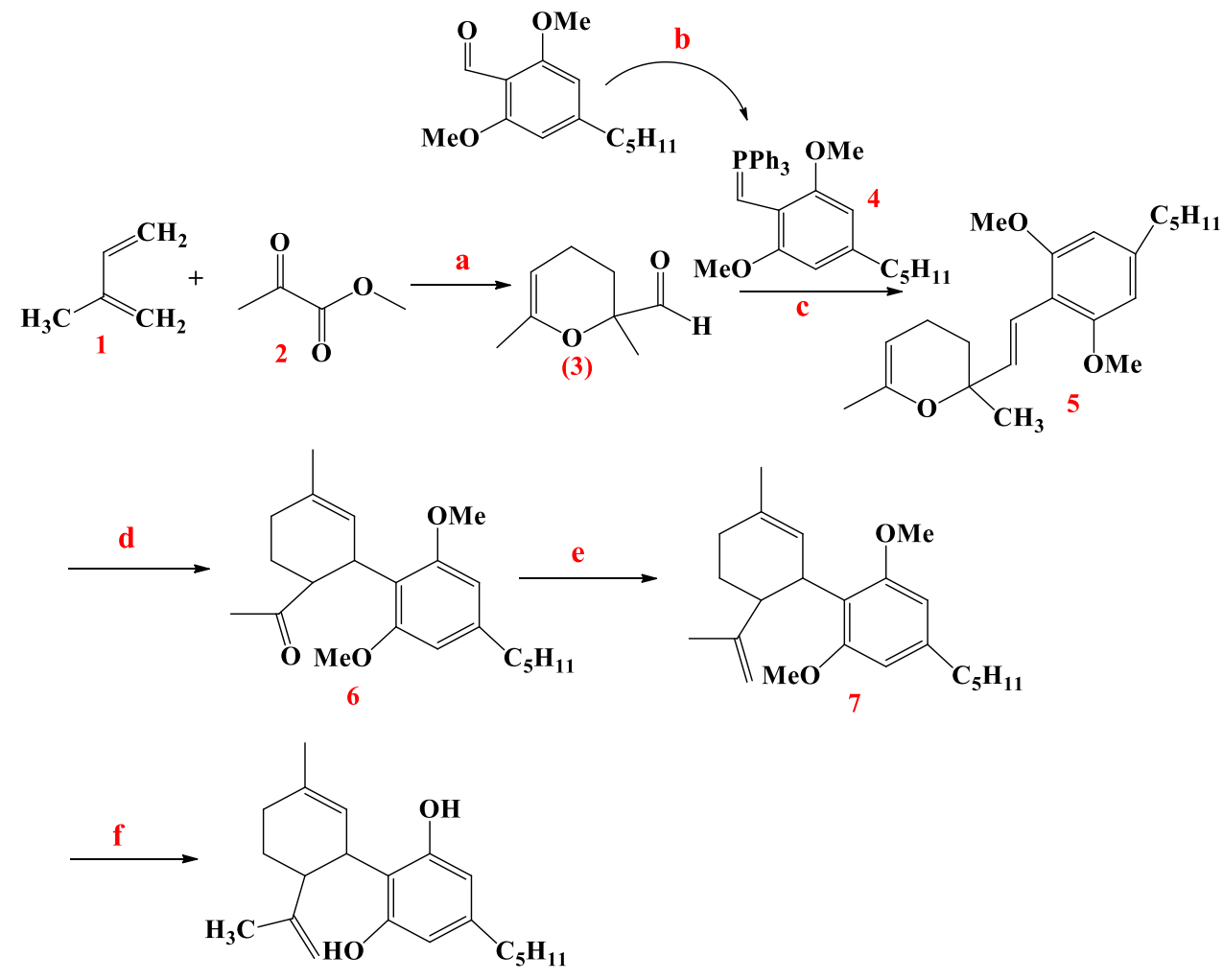

$( \pm)-\mathrm{CBD}$ of $\alpha, \beta$-unsaturated enone with sodium borohydride and acylation with vinyl butyrate under enzymatic conditions (Savinase $12 \mathrm{~T}$ ) provided allyl alcohol. Acylation of this allyl alcohol with acid after the Ireland-Claisen rearrangement provided carboxylic acid. Methylation carboxylic acid caused the formation of the corresponding ketone. CBD is produced by the Wittig olefination with $\mathrm{Ph}_{3} \mathrm{P}=\mathrm{CH}_{2}$ and deprotection (Fig. 25). They have achieved CBD via inexpensive and available enzyme Savinase $12 \mathrm{~T}$.

Stunder et al. used organometallic intermediates for the synthesis of CBD. For this method, they used alkyl derivatives of $(S)$-perillic acid (1). They produced the aryl iodide (3) for the arylation of olefins. For this synthesis, they used (5) in the presence of KI, $m$-CPBA, and crown- 6 followed 
Fig. 20 Reagents: a $\mathrm{Sc}(\mathrm{OTf})_{3}$, $\mathrm{MgSO}_{4}, \mathrm{CH}_{2} \mathrm{Cl}_{2}, 10^{\circ} \mathrm{C}, 3 \mathrm{~h}$ and b $\mathrm{NaOH}, \mathrm{MeOH}$, reflux, $5 \mathrm{~h}$, $44 \%$

Fig. 21 Reagents: $\mathbf{a} \mathrm{Br}_{2}$, $\mathrm{CH}_{2} \mathrm{Cl}_{2},-50{ }^{\circ} \mathrm{C}, 15 \mathrm{~min}, 82 \%$; b $\rho-\mathrm{TsOH} \cdot \mathrm{H}_{2} \mathrm{O}, \mathrm{CH}_{2} \mathrm{Cl}_{2},-35^{\circ} \mathrm{C}$ and $\mathbf{c} \mathrm{Na}_{2} \mathrm{SO}_{3}$, ascorbic acid, $\mathrm{Et}_{3} \mathrm{~N}, \mathrm{MeOH}, 75^{\circ} \mathrm{C}, 16 \mathrm{~h}, 78 \%$<smiles>C=C(C)[C@H]1C=CC(C)(O)CC1</smiles>

(1)

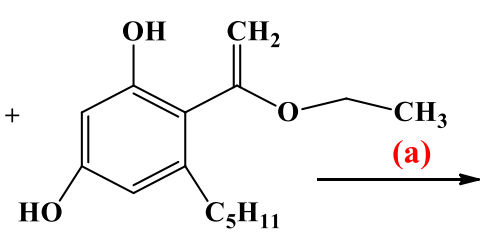

(2)

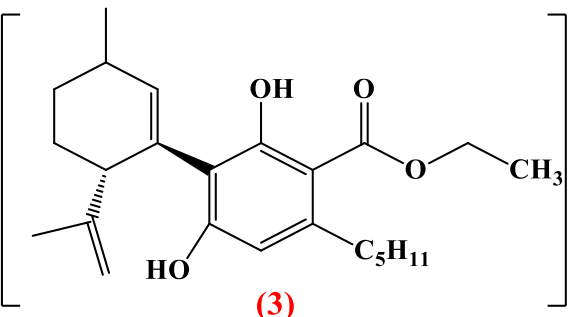

(3)<smiles>C=C(C)[C@H]1CCC(C)=C[C@@H]1c1c(O)cc(CCCCCC)cc1O</smiles>

(-)-CBD<smiles>C=C(C)[C@H]1CCC(C)C=C1c1c(O)c(Br)c(CCCCC)c(Br)c1O</smiles>

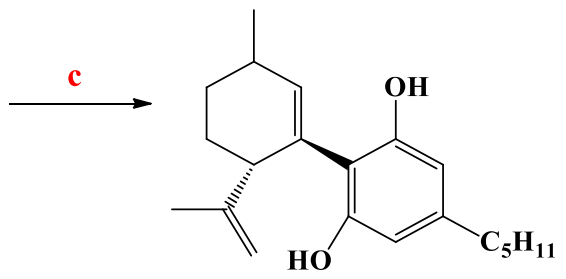

(-)-CBD

Fig. 22 Reagents: a $\mathrm{NiCl}_{2}$ (tpp) $)_{2}$, TMEDA, rt, overnight; $\mathbf{b}$ 1. $\mathrm{CrO}_{3}, \mathrm{H}_{2} \mathrm{SO}_{4}$. 2. I $\mathrm{I}_{2}$, DBHQ, $\mathrm{Py} ; \mathbf{c} \mathrm{Ar}_{2} \mathrm{Cu}(\mathrm{CN}) \mathrm{Li}_{2}, \mathrm{BF}_{3} \cdot \mathrm{OEt}_{2}$, $\mathrm{Et}_{2} \mathrm{O},-78^{\circ} \mathrm{C}, 2 \mathrm{~h} ; \mathbf{d} 1$. EtMgBr . 2. $\mathrm{ClP}(\mathrm{O})(\mathrm{OEt})_{2}$, THF, $0{ }^{\circ} \mathrm{C}$, $2 \mathrm{~h}$; e $\mathrm{MeMgCl}, \mathrm{Ni}(\mathrm{acac})_{2}$, THF, $\mathrm{rt}$ and $\mathrm{f} \mathrm{MeMgI}, 155-165^{\circ} \mathrm{C}$

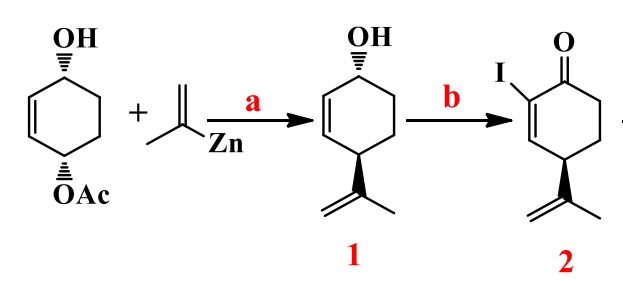

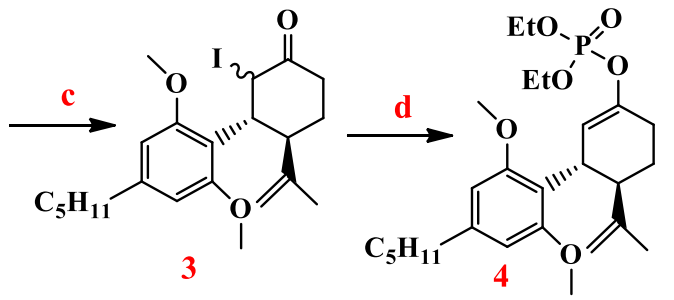

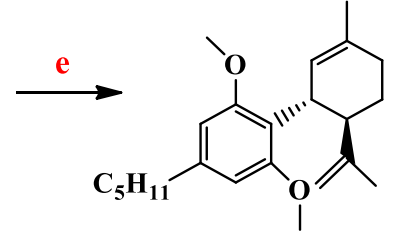

5

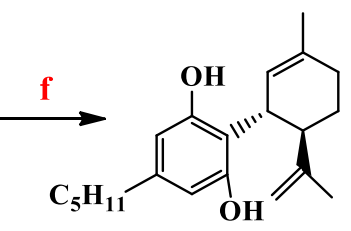

(-)-CBD 
Fig. 23 Reagents: a (2), CSA, $\mathrm{CH}_{2} \mathrm{Cl}_{2}, 20^{\circ} \mathrm{C}, 3 \mathrm{~h}, 73 \%$; b $\mathrm{MsCl}, \mathrm{Et}_{3} \mathrm{~N}, \mathrm{CH}_{2} \mathrm{Cl}_{2} ; 0^{\circ} \mathrm{C}, 1 \mathrm{~h}$, then $20{ }^{\circ} \mathrm{C}, 16 \mathrm{~h}, 89 \%$ and $\mathbf{c}$ MeLi, THF, $0{ }^{\circ} \mathrm{C}, 1 \mathrm{~h}, 70 \%$<smiles>CCCCCCc1cc(O)cc(O)c1</smiles>

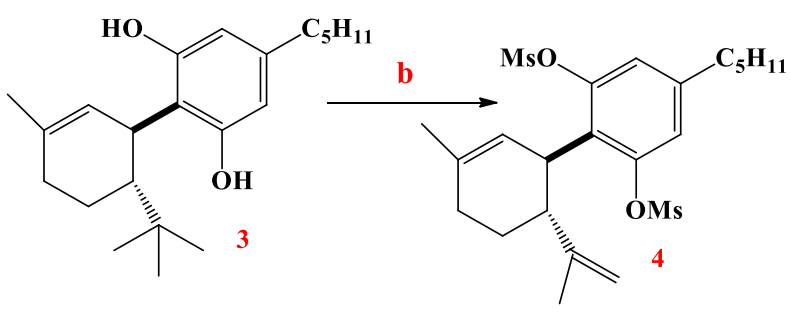

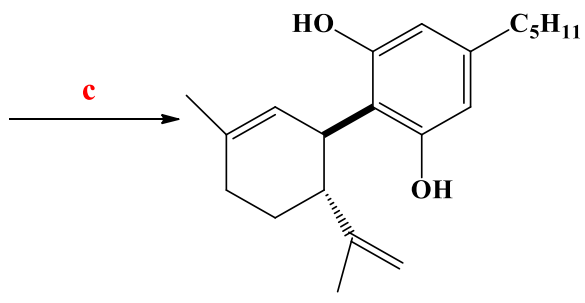

$( \pm)-C B D$
Fig. 24 Reagents: a DielsAlder, $11 \mathrm{kbar}, 55^{\circ} \mathrm{C}$; b $\left(\mathrm{NaHCO}_{3}\right)_{\mathrm{aq}}, \mathrm{PH}=8.3,150^{\circ} \mathrm{C}$; c $\mathrm{CH}_{3} \mathrm{MgI}$ and $\mathbf{d ~} \mathrm{SOCl}_{2}$, Py
Fig. 25 Reagents: a 1. $\mathrm{Me}_{2} \mathrm{SO}_{4}$, $\mathrm{K}_{2} \mathrm{CO}_{3}, 80^{\circ} \mathrm{C}$. 2. S-BuLi, DMF, $-78^{\circ} \mathrm{C}$ to rt. 3 . NaOH, $\mathrm{Me}_{2} \mathrm{CO}, 60^{\circ} \mathrm{C}$; b $1 . \mathrm{NaBH}_{4} .2$. Savinase $12 \mathrm{~T}$, vinyl butyrate. 3. $\mathrm{NaOH}, \mathrm{H}_{2} \mathrm{O}$, EtOH, reflax; c oxazaborolidine, $\mathrm{BH}_{3} \mathrm{THF}$, toluene, $-78^{\circ} \mathrm{C}, \mathbf{d} 1$. DCC, DMAP. 2. KHMDS, $-78^{\circ} \mathrm{C}$. 3. TMSCL, py, $-78^{\circ} \mathrm{C}$ to rt; $\mathbf{e}$ MeLi and $\mathbf{f} 1$. Grubb's 2nd gen. 2. $\mathrm{Ph}_{3} \mathrm{P}=\mathrm{CH}_{2}, 75^{\circ}$ C. 3. MeMgI, $160{ }^{\circ} \mathrm{C}$

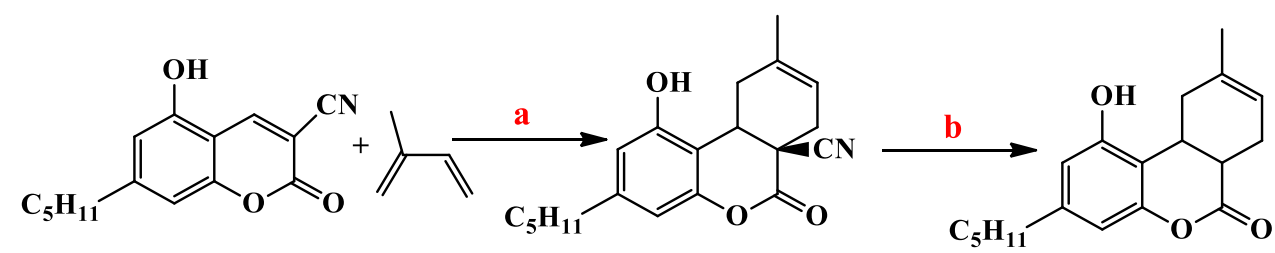

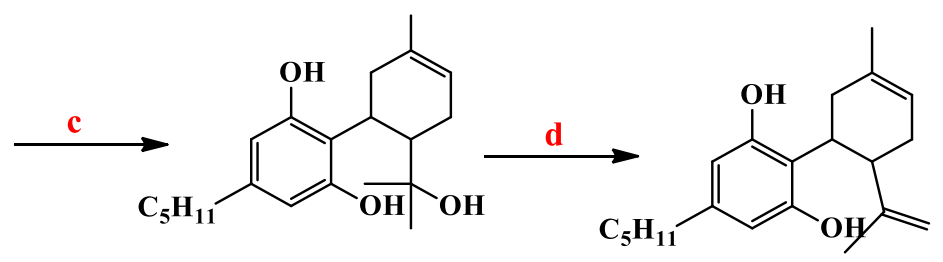

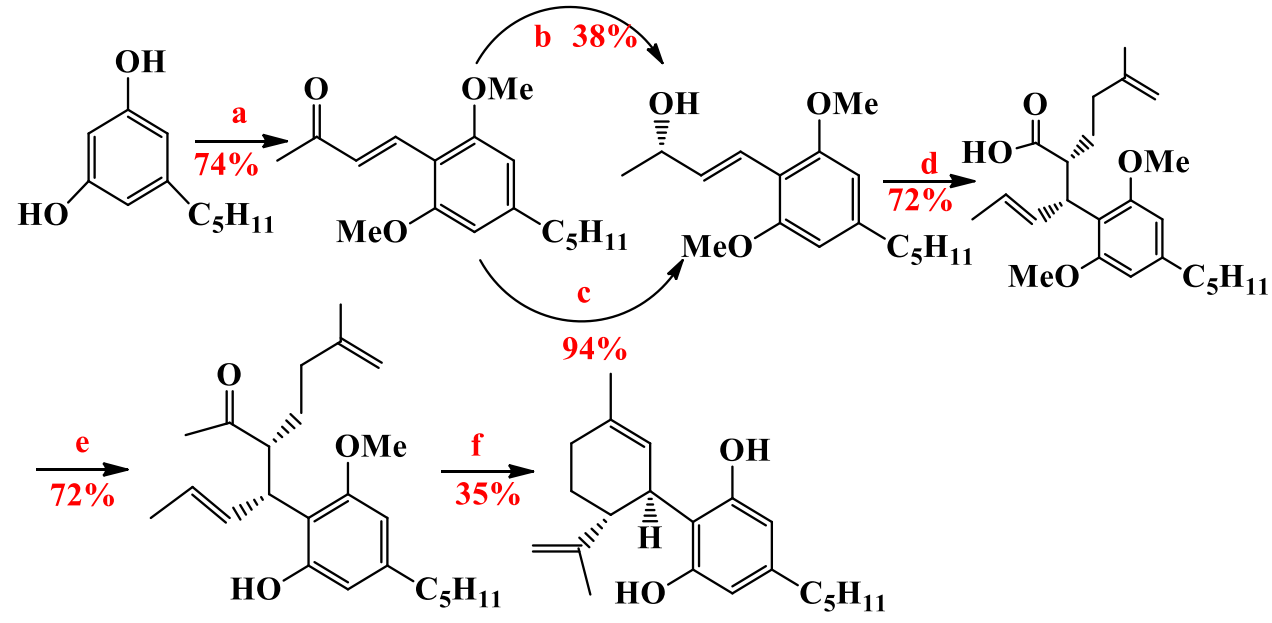

(-)-CBD 
by methylation of dimethyl sulfide $\left(\mathrm{Me}_{2} \mathrm{~S}\right)$. Finally, decarboxylation of (2) with Pd catalyze provided the (+)-CBD in $73 \%$ yield (Fig. 26) [97].

Keasling et al. used biosynthesis routes for the synthesis of cannabinoids. They used geranyl pyrophosphate (GPP) and olivetolic acid and produced Cannabigerolic acid (CBGA). Cannabigerolic acid was converted to cannabidiolic acid (CBDA) by the cannabinoid synthases CBDAS. CBD was produced after CBDA decarboxylate by heat (Fig. 27) [98].

Marson et al. have proposed a new method to synthesize CBD [99]. Olivetol was condensed with the diol under optimized Friedel-Crafts conditions and the triol has been achieved in $73 \%$ yield. The mesylation of triol with $\mathrm{Et}_{3} \mathrm{~N}$ eliminated the isopropenyl group and then the mesylate groups were removed by methyllithium which made (+)-cannabidiol in good yield (Fig. 28).

A new synthetic route for production of (-)-CBD and its derivatives are developed by Jingshan Shen et al. [100]. They used Friedel-Crafts alkylation of A with benzene-1,3,5-triol (phloroglucinol) and formed regioselective triflation 1 in $80 \%$ yield. They used (1) with $\mathrm{Tf}_{2} \mathrm{O}$ to prepare aryl triflate (2) in $78.1 \%$ yield. They used the Negishi cross-coupling
Fig. 26 Reagents: a 1. LDA, THF, $-78^{\circ} \mathrm{C}, 2$ h. 2 . DMPU, 15 min. 3. DMPU, 15 min, 90\%; b (3), [Pd(dba) $\left.{ }_{2}\right], \mathrm{PhMe}$, $\mathrm{Cs}_{2} \mathrm{CO}_{3}, 110^{\circ} \mathrm{C}, 26 \mathrm{~h}, 74 \%$; d KI, m-CPBA, 18-crown-6, $\mathrm{CH}_{2} \mathrm{Cl}_{2}, 0^{\circ} \mathrm{C}, 67 \%$, e $\mathrm{CH}_{3} \mathrm{I}$, $\mathrm{K}_{2} \mathrm{CO}_{3}$, DMF, r.t. $87 \%$

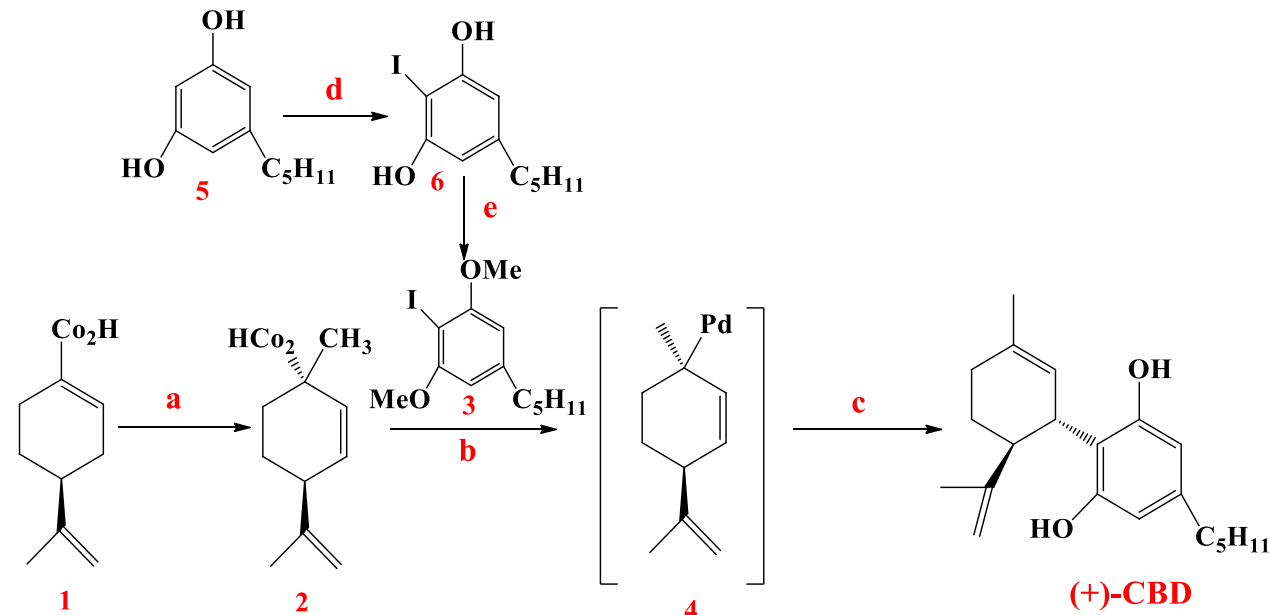

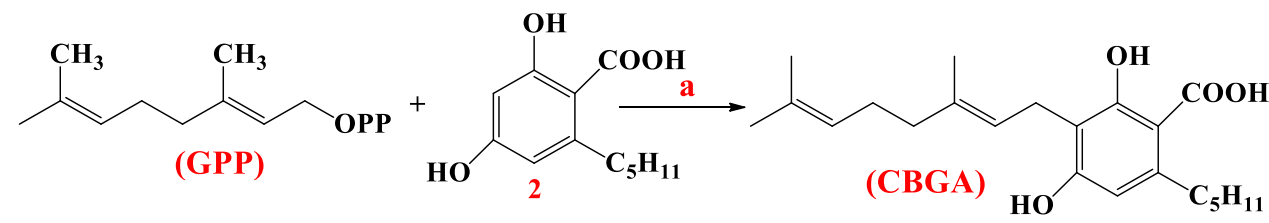

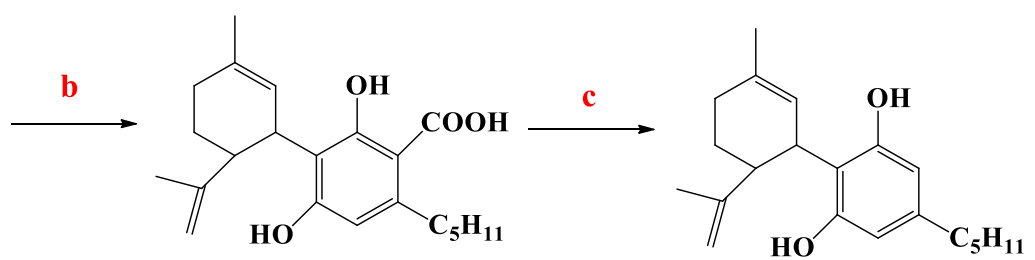

(CBDA)

(CBD)

Fig. 28 Reagents: a CSA, $\mathrm{CH}_{2} \mathrm{Cl}_{2} ; \mathbf{b}$ methanesulfonyl chloride, $\mathrm{Et}_{3} \mathrm{~N}, \mathrm{CH}_{2} \mathrm{Cl}_{2}$ and $\mathbf{c}$ methyllithium, THF
Fig. 27 Reagents: a CsPT4, b CBDAS and $\mathbf{c}$ heat $(\Delta T)$ 
Fig. 29 Reagents: $\mathbf{a} \mathrm{BF}_{3}, \mathrm{Et}_{2} \mathrm{O}$, THF; $\mathbf{b} \mathrm{Tf}_{2} \mathrm{O}, 2$,6-lutidine, DCM; c $\mathrm{C}_{5} \mathrm{H}_{11} \mathrm{ZnCl}, \mathrm{Pd}(\mathrm{dppf})$ $\mathrm{Cl}_{2}, \mathrm{LiCl}$, THF; d Pd(dppf)Cl ${ }_{2}$, $\mathrm{LiCl}$, THF and $\mathbf{e} \mathrm{CH}_{3} \mathrm{MgBr}$, toluene, $110^{\circ} \mathrm{C}, 12 \mathrm{~h}$

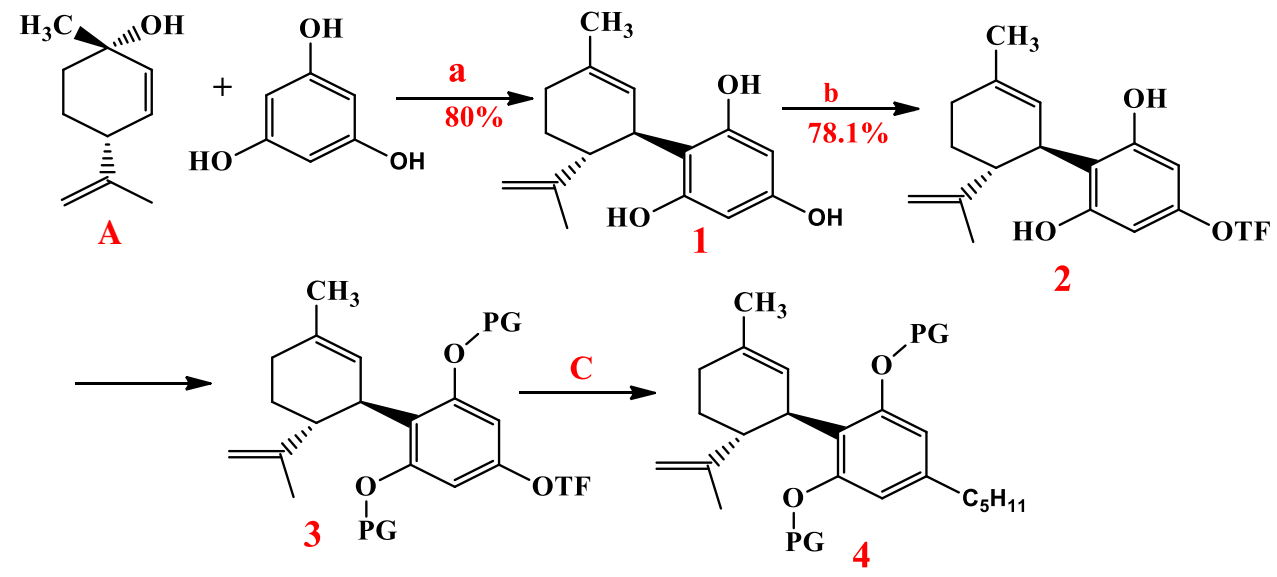

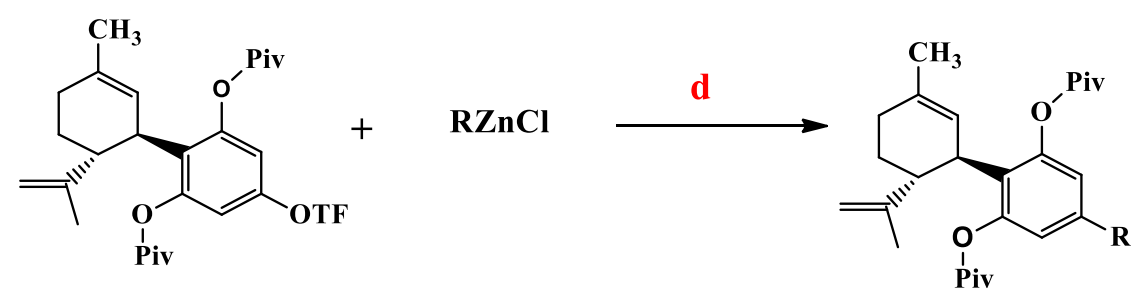

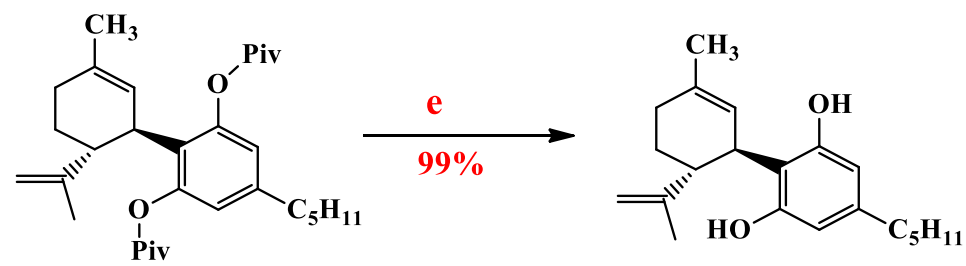

(-)-CBD for phenolic hydroxyl protection. Also, for obtaining CBD efficiently, they used $\mathrm{C}_{5} \mathrm{H}_{11} \mathrm{ZnCl}$ with lithium chloride in the presence of 1,1'-bis(diphenylphosphino)ferrocene] dichloropalladium(II) $\left(\mathrm{Pd}(\mathrm{dppf}) \mathrm{Cl}_{2}\right.$ ) catalyst and the highest yield was about $20 \%$. In this procedure, the phenolic protecting group developed the intermediate organopladium by the Negishi cross-coupling reaction. Also, they found out that the pivalate group was a great protection group; hence, (-)-CBD-2OPiv-OTf was chosen. For achieving the best $99 \%$ yield of CBD, the Piv group must be omitted, so de-protection was done (Fig. 29).

\section{Conclusions}

Clinical researches showed effects of $\Delta^{9}$-THC and CBD in multiple illnesses such as multiple sclerosis, HIV/AIDS arising from anorexia and chemotherapy, from nausea and vomiting, multiple sclerosis autism, inflammation, neuropathic pain, cancer, Epilepsy and Covid-19. Cannabinoid receptors 1 and 2 (CB1 and CB2) interfere in many processes responsible for inflammation, redox activity, cellular metabolism and mitochondrial activity. These compounds are well applicable to provide different drugs too. These compounds are used to make four drugs of Dronabinol, Epidiolex, Nabiximols and Nabilone. In this review, we report numerous synthetic synthesis pathways for $\Delta^{9}$-THC and CBD. Synthetic synthesis of $\Delta^{9}$-tetrahydrocannabinol and cannabidiol instead of extracting them from plants eliminates the problems associated with cultivation and extraction but this method still needs more preparation. Preparing new optimal methods for the synthetic synthesis of cannabinoids will cause the promotion of novel drugs.

Acknowledgements This work supported by the "Iran National Science Foundation: INSF" and the University of Zanjan. Also, the present work has been done in line with Neda Tadayon Ph.D. Thesis. 


\section{References}

1. R.S. Rapaka, A. Makriyannis, National Institute on Drug Abuse (Rockville, MD, 1987).

2. R. Mechoulam, N.K. McCallum, S. Burstein, Chem. Rev. 76, 75-112 (1976)

3. L.R. Hanuš, S.M. Meyer, E. Muñoz, O. Taglialatela-Scafati, G. Appendino, Nat. Prod. Rep. 33, 1357-1392 (2016)

4. T.A. Reekie, M.P. Scott, M. Kassiou, Nat. Rev. Chem. 2, 0101 (2017)

5. Y. Gaoni, R. Mechoulam, J. Am. Chem. Soc. 86, 1646-1647 (1964)

6. D.M. Lambert, C.J. Fowler, J. Med. Chem. 48, 5059-5087 (2005)

7. R. Adams, M. Hunt, J.H. Clark, J. Am. Chem. Soc. 62, 196-200 (1940)

8. R. Mechoulam, Y. Shvo, Tetrahedron 19, 2073-2078 (1963)

9. Y. Gaoni, R. Mechoulam, Tetrahedron Lett. 12, 1109-1111 (1967)

10. L.E. Long, D.T. Malone, D.A. Taylor, Drugs Future 30, 747-753 (2005)

11. L.A. Matsuda, S.J. Lolait, M.J. Brownstein, A.C. Young, T.I. Bonner, Nature 346, 561-564 (1990)

12. S. Munro, K.L. Thomas, M. Abu-Shaar, Nature 365, 61-65 (1993)

13. W.A. Devane, F.A. Dysarz, M.R. Johnson, L.S. Melvin, A.C. Howlett, Mol. Pharmacol. 34, 605-613 (1988)

14. M. Herkenham, A.B. Lynn, M.D. Little, M.R. Johnson, L.S. Melvin, B.R. de Costa, K. C. Rice 87, 1932-1936 (1990)

15. M. Herkenham, A.B. Lynn, M.R. Johnson, L.S. Melvin, B.R. de Costa, K.C. Rice J. Neurosci. 11, 563-583 (1991)

16. R.G. Pertwee, Curr. Med. Chem. 6, 635-664 (1999)

17. J.W. Huffman, J.A.H. Lainton, Curr. Med. Chem. 3, 101-106 (1996)

18. S. Munro, K.L. Thomas, M. Abu-Shar, Nature 365, 61-65 (1993)

19. R. Mechoulam, M. Peters, E.M. Rodriguez, L.O. HanušL, Chem. Biodivers. 4, 1678-1692 (2007)

20. R.G. Pertwee, Br. J. Pharmacol. 153, 199-215 (2008)

21. Marinol (Dronabinol) (PDF). US Food and Drug Administration. September 2004. Retrieved 14 January 2018.

22. Cannabis and Cannabinoids. National Cancer Institute. 2011-1024. Retrieved 12 January (2014)

23. List of psychotropic substances under international control. International Narcotics Control Board. International Narcotics Control Board. Retrieved 25 April 2018. This international non-proprietary name refers to only one of the stereochemical variants of delta-9-tetrahydrocannabinol, namely (-)-trans-delta-9-tetrahydrocannabinol

24. J.W. Chen, L.M. Borgelt, A.B. Blackmer, Ann. Pharmacother. 53, 603 (2019)

25. B. Jung, J.K. Lee, J. Kim, E.K. Kang, S.Y. Han, H.Y. Lee, I.S. Choi, Chem. Asian J. 379, 795-795 (2018)

26. S.R. Calhoun, G.P. Galloway, D.E. Smith, J. Psychoactive Drugs 30, 187-196 (1998)

27. WHO Expert Committee on Drug Dependence. World Health Organization. Retrieved 12 January (2014)

28. P. Morales, P.H. Reggio, N. Jagerovic, Front. Pharmacol. 8, 422-440 (2017)

29. FDA approves first drug comprised of an active ingredient derived from marijuana to treat rare, severe forms of epilepsy. US Food and Drug Administration (FDA). June 25 (2018)

30. J. Elliott, D. DeJean, T. Clifford, D. Coyle, B.K. Potter, B. Skidmore, C. Alexandere, A.E. Repetski, V.S.B. McCoy, G.A. Wells, Seizure 75, 18-22 (2020)

31. A.R. de Mello Schier, N.P. de Oliveira Ribeiro, D.S. Coutinho, S. Machado, O. Arias-Carrion, J.A. Crippa, A.W. Zuardi, A.E.
Nardi, A.C. Silva, CNS Neurol. Disord. Drug Targets 13, 953 960 (2014)

32. P. Massi, M. Solinas, V. Cinquina, D. Parolaro, Br. J. Clin. Pharmacol. 75, 303-312 (2013)

33. S. Bhattacharyya, P.D. Morrison, P. Fusar-Poli, R. MartinSantos, S. Borgwardt, T. Winton-Brown, C. Nosarti, M. Seal, P. Allen, M.A. Mehta, J.M. Stone, N. Tunstall, V. Giampietro, S. Kapur, R.M. Murray, A.W. Zuardi, J.A. Crippa, Z. Atakan, P.K. McGuire, Neuropsychopharmacol. 35, 764-774 (2010)

34. S. Burstein, Bioorg. Med. Chem. 23, 1377-1385 (2015)

35. A. Gegotek, S. Atalay, P. Domingues, E. Skrzydlewska, Cells 8, 995 (2019)

36. L. Ruiz-Valdepenas, J.A. Martinez-Orgado, C. Benito, A. Millan, R.M. Tolon, J. Romero, J. Neuroinflammation 8, 5-14 (2011)

37. S.D. McAllister, R. Murase, R.T. Christian, D. Lau, A.J. Zielinski, J. Allison, C. Almanza, A. Pakdel, J. Lee, C. Limbad, Y. Liu, R.J. Debs, D.H. Moore, P.Y. Desprez, Breast Cancer Res. Treat. 129, 37-47 (2011)

38. G.P. Silote, A. Sartim, A. Sales, A. Eskelund, F.S. Guimaraes, G. Wegener, S. Joca, J. Chem. Neuroanat. 98, 104-116 (2019)

39. C. Ibeas Bih, T. Chen, A.V. Nunn, M. Bazelot, M. Dallas, B.J. Whalley, Neurotherapeutics 12, 699-730 (2015)

40. L. Steardo, M.R. Bronzuoli, A. Iacomino, G. Esposito, L. Steardo, C. Scuderi, Front. Neurosci. 9, 259-268 (2015)

41. J. Fernandez-Ruiz, O. Sagredo, M.R. Pazos, C. Garcia, R. Pertwee, R. Mechoulam, J. Martinez-Orgado, Br. J. Clin. Pharmacol. 75, 323-333 (2013)

42. F. Wu, S. Zhao, B. Yu, Nature 579(7798), 265-269 (2020)

43. C.C. Lai, T.P. Shih, W.C. Ko et al., Int. J. Antimicrob. Agents. 55(3), 105924 (2020)

44. C.T. Costiniuk, M.A. Jenabian, Cytokine Growth Factor Rev. 53, 63-65 (2020)

45. Q. Long, X. Tang, Q. Shi et al. Nature Med. 020-0965-6 (2020)

46. M.D. Rizzo, J.E. Henriquez, L.K. Blevins, A. Bach, R.B. Crawford, N.E.J. Kaminski, Neuroimmune Pharmacol. 09918-7 (2020)

47. F. Rossi, C. Tortora, M. Argenziano, A. Di Paola, F. Punzo, Int. J. Mol. Sci. 21, 2757 (2020)

48. A. Olah, Z. Szekanecz, T. Biro, Front Immunol. 8, 1487 (2017)

49. O.R. Almogi-Hazan, Int. J. Mol. Sci. 21(12), E448 (2020)

50. A. Tahamtan, M. Tavakoli-Yaraki, V. Salimi, Expert Rev. Resp. Med. 14, 965-967 (2020)

51. S.W. Mamber, S. Krawkowka, J. Osborn et al., MSphere 5, e00288 (2020)

52. A. Sattari, A. Ramazani, H. Aghahosseini, Res. Square. https:// doi.org/10.21203/rs.3.rs-37994/v1 (2020)

53. A. Zarei, S. Taghavi Fardood, F. Moradnia, A. Ramazani, Euras. Chem. Commun. 2, 798-811 (2020)

54. A. Meza, C. Lehmann, Med. Hypotheses 110, 68-70 (2018)

55. R. Obeid, W. Herrmann, FEBS Lett. 580, 2994-3005 (2006)

56. Rk. Naviaux, MITOCH 16, 7-17 (2014)

57. F.G. Horhat, A.F. Rogobete, M. Papurica, D. Sandesc, S. Tanasescu, V. Dumitrascu, M. Licker, R. Nitu, C.A. Cradigati, M. Sarandan et al., Clin. Lab. 62, 1601-1607 (2016)

58. A.C. Melo, S.S. Valença, L.B. Gitirana, J.C. Santos, L.M. Ribeiro, M.N. Machado, C.B. Magalhães, W.A. Zin, L.C. Porto, Int. Immunopharmacol. 17, 57-64 (2013)

59. A. Moise, Centr. Eur. J. Clin. Res. 1, 59-66 (2018)

60. M. Sandesc, A.F. Rogobete, O.H. Bedreag, A. Dinu, M. Papurica, C.A. Cradigati, M. Sarandan, S.E. Popovici, L.M. Bratu, T. Bratu et al., Bosn. J. Basic Med. Sci. 18, 191-197 (2018)

61. X. Luo, M.A. Reiter, L. d'Espaux, J. Wong, C.M. Denby, A. Lechner, Y. Zhang, A.T. Grzybowski, S. Harth, W. Lin, H. Lee, C. Yu, J. Shin, K. Deng, V.T. Benites, G. Wang, E.E.K. Baidoo, Y. Chen, I. Dev, C.J. Petzold, J.D. Keasling, Nature 567, 123-126 (2019) 
62. R. Mechoulam, P. Braun, Y. Gaoni, J. Am. Chem. Soc. 89, 45524554 (1967)

63. R. Mechoulam, P. Braun, Y. Gaoni, J. Am. Chem. Soc. 94, 61596165 (1972)

64. R. Razdan, A. Puttick, B. Zitko, G. Handrick, Experientia 28, 121-122 (1972)

65. D.A. Evans, E.A. Shaughnessy, D.M. Barnes, Tetrahedron Lett. 38, 3193-3194 (1997)

66. A.D. William, Y. Kobayashi, Synthesis of tetrahydrocannabinols based on an indirect 1,4-addition strategy. J. Org. Chem. 67, 8771-8782 (2002)

67. B.M. Trost, K. Dogra, Org. Lett. 9, 861-863 (2007)

68. L. Minuti, E. Ballerini, J. Org. Chem. 76, 5392-5403 (2011)

69. L.J. Cheng, J.H. Xie, Y. Chen, L.X. Wang, Q.L. Zhou, Org. Lett. 15, 764-767 (2013)

70. Z.P. Shultz, G.A. Lawrence, J.M. Jacobson, E.J. Cruz, J.W. Leahy, Org. Lett. 20, 381-384 (2018)

71. P.D. Giorgi, V. Liautard, M. Pucheault, S. Antoniotti, Eur. J. Org. Chem. 11, 1307-1311 (2018)

72. A. Ametovski, D.W. Lupton, Org. Lett. 21, 1212-1215 (2019)

73. M.A. Schafroth, G. Zuccarello, S. Krautwald, D. Sarlah, E.M. Carreira, Angew. Chem. Int. Ed. 53, 13898-13901 (2014)

74. T. Petrzilka, W. Haefliger, C. Sikemeier, Helv. Chim. Acta 52, 1102 (1969)

75. S.L. Rössler, D.A. Petrone, E.M. Carreira, Acc. Chem. Res. 52, 2657-2672 (2019)

76. T.D. Kiselaka, R. Koerbera, G.F. Verbecka. Forensic Sci. Int. 308 (2020)

77. R. Mechoulam, Y. Gaoni, J. Am. Chem. Soc. 87, 3273-3275 (1965)

78. T. Petrzilka, C. Sikemeier, Helv. Chim. Acta. 50, 2111-2113 (1967)

79. T. Petrzilka, W. Haefliger, C. Sikemeier, G. Ohloff, A. Eschenmoser, Helv. Chim. Acta. 50, 719-723 (1967)

80. S.H. Baek, M. Srebnik, R. Mechoulam, Tetrahedron Lett. 26, $1083(1985)$

81. F. Korte, E. Dlugosch, U. Justus Liebigs Ann. Chem. 693(1), 165-170 (1966)

82. F. Korte, E. Hackel, H. Sieper, Justus Liebigs Ann. Chem. 685(1), 122-128 (1965)

83. U. Claussen, F.V. Spulak, F. Korte, Tetrahedron 22(4), 14771479 (1966)

84. H. Kōchi, M. Matsui, Agric. Biol. Chem. 31(5), 625-627 (1967)

85. W.E. Childers, H.W. Pinnick, J. Org. Chem. 49(26), 5276-5277 (1984)

86. D.C. Burdick, S.J. Collier, F. Jos, B. Betina, H. Meckler, M.A. Helle, W. Habersha, Process for production of delta-9-tetrahydrocannabinol (2010)

\section{Authors and Affiliations}

\section{Neda Tadayon ${ }^{1} \cdot$ Ali Ramazani ${ }^{1,2,3,4}$ [D}

\section{Ali Ramazani}

aliramazani@gmail.com; aliramazani@znu.ac.ir

1 Department of Chemistry, Faculty of Science, University of Zanjan, 45371-38791 Zanjan, Iran

2 Department of Biotechnology, Research Institute of Modern Biological Techniques (RIMBT), University of Zanjan, 45371-38791 Zanjan, Iran
87. D. Lukas, P. Denis, W. Ulrich, D. Petrovic, L. Dialer, U. Weigl, D. Petrovic, U. Weig, Process for the production of cannabidiol and delta-9 Tetrahydrocannabinol (2018)

88. Y. Kobayashi, A. Takeuchi, Y.G. Wang, Org. Lett. 8, 2699-2702 (2006)

89. A.D. William, Y. Kobayashi, Org. Lett. 3, 2017-2020 (2001)

90. D. Zhu, L. Shi, Chem. Commun. 54, 9313-9316 (2018)

91. A. Joshi-Pangu, C.-Y. Wang, M.R. Biscoe, J. Am. Chem. Soc. 133, 8478-8481 (2011)

92. A.D. William, Y. Kobayashi, J. Org. Chem. 67, 8771-8782 (2002)

93. J.A. Teske, A. Deiters, Org. Lett. 10, 2195-2198 (2008)

94. E. Ballerini, L. Minuti, O. Piermatti, F. Pizzo, J. Org. Chem. 74, 4311-4317 (2009)

95. G.R. Handrick, R.K. Razdan, D.B. Uliss, H.C. Dalzell, E. Boger, J. Org. Chem. 42, 2563-2568 (1977)

96. G. Brufola, F. Fringuelli, O. Piermatti, F. Pizzo, Heterocycles 43, 1257-1266 (1996)

97. F. Klotter, A. Studer, Angew. Chemie Int. Ed. 54(29), 8547-8550 (2015)

98. X. Luo, M.A. Reiter, L. d'Espaux et al., Nature 567, 123-126 (2019)

99. T.M. Waugh, J. Masters, A.E. Aliev, C.M. Marson, Chem. Med. Chem. 14, 1-12 (2019)

100. X. Gong, C. Sun, M.A. Abame, W. Shi, Y. Xie, W. Xu, F. Zhu, Y. Zhang, J. Shen, H.A. Aisa, J. Org. Chem. 85, 2704-2715 (2020)

101. C. Silvestri, V. Di Marzo, Cell Metab. 17, 475-490 (2013)

102. I. Khuja, Z. Or, R. Yekhtin, O. Almogi-Hazan, Int. J. Mol. Sci. 20, 668 (2019)

103. R. Mechoulam, L.A. Parker, Annu. Rev. Psychol. 64, 21-47 (2013)

104. L. Ruiz-valdepeñas, J.A. Martínez-orgado, C. Benito, A. Millán, R.M. Tolón, An intravital micros. J. Neuroinflamm. 8, 5 (2011)

105. L. Palomba, C. Silvestri, R. Imperatore, G. Morello, F. Piscitelli, A. Martella, L. Cristino, V. Di, Marzo. J. Biol. Chem. 290, 13669-13677 (2015)

106. S. Sun, F. Hu, J. Wu, S. Zhang, Redox Biol. 11, 577-585 (2017)

107. A. Alexander, P.F. Smith, R.J. Rosengren, Cancer Lett. 285, 6-12 (2009)

108. A.J. Id, F. Gao, G. Coppola, Z. Vogel, E. Kozela, PLoS ONE 14, $\mathrm{e} 0212039$ (2019)

109. G. Esposito, C. Scuderi, M. Valenza, G.I. Togna, V. Latina, T. Iuvone, L. Steardo, D. De Filippis, M. Cipriano, M.R. Carratu, PLoS ONE 6, 28668 (2011)

110. M. Mecha, A.S. Torrao, L. Mestre, F.J. Carrillo-salinas, R. Mechoulam, C. Guaza, Cell Death Discov. 3, 331 (2012)

111. X. Luo, M.A. Reiter, L. d'Espaux et al., Nature 567, 123-126 (2019)
3 Department of Agronomy, Research Institute of Modern Biological Techniques (RIMBT), University of Zanjan, 45371-38791 Zanjan, Iran

4 Department of Animal Science, Research Institute of Modern Biological Techniques (RIMBT), University of Zanjan, 45371-38791 Zanjan, Iran 